\title{
THE WELL-BEING OF THE OVEREMPLOYED AND THE UNDEREMPLOYED AND THE RISE IN DEPRESSION IN THE UK
}

\author{
David N.F. Bell \\ David G. Blanchflower \\ Working Paper 24840 \\ http://www.nber.org/papers/w24840
NATIONAL BUREAU OF ECONOMIC RESEARCH
1050 Massachusetts Avenue
Cambridge, MA 02138
July 2018

The views expressed herein are those of the authors and do not necessarily reflect the views of the National Bureau of Economic Research.

NBER working papers are circulated for discussion and comment purposes. They have not been peer-reviewed or been subject to the review by the NBER Board of Directors that accompanies official NBER publications.

(C) 2018 by David N.F. Bell and David G. Blanchflower. All rights reserved. Short sections of text, not to exceed two paragraphs, may be quoted without explicit permission provided that full credit, including $\odot$ notice, is given to the source. 
The Well-being of the Overemployed and the Underemployed and the Rise in Depression in the UK

David N.F. Bell and David G. Blanchflower

NBER Working Paper No. 24840

July 2018

JEL No. I20,I31,J64

\section{ABSTRACT}

In this paper we build on our earlier work on underemployment using data from the UK. In particular, we explore their well-being based on hours preferences rather than on involuntary part-time work used in the prior literature. We make use of five main measures of well-being: happiness; life satisfaction; whether life is worthwhile; anxiety and depression. The underemployed have higher levels of well-being than the unemployed and disabled but lower levels than any other group of workers, full or part-time. The more that actual hours differ from preferred hours the lower is a worker's well-being. This is true for those who say they want more hours (the underemployed) and those who say they want less (the over employed).

We find strong evidence of a rise in depression and anxiety (negative affect) in the years since the onset of austerity in 2010 that is not matched by declines in happiness measures (positive affect). The fear of unemployment obtained from monthly surveys from the EU has also been on the rise since 2015. We find evidence of an especially large rise in anxiety and depression among workers in general and the underemployed in particular. The underemployed don't want to be underemployed.

David N.F. Bell

Division of Economics

Stirling Management School

University of Stirling

FK9 4LA

United Kingdom

d.n.f.bell@stir.ac.uk

David G. Blanchflower

Bruce V. Rauner Professor of Economics

6106 Rockefeller Hall

Dartmouth College

Hanover, NH 03755-3514

and NBER

David.G.Blanchflower@Dartmouth.EDU 
Underemployment has replaced unemployment as the main measure of labor market slack in the UK in the years since 2008. Indeed, as noted by Jensen and Slack (2003), 'underemployment was proposed as a more exhaustive and hence more valid measure of employment hardship than mere unemployment'. Underemployment is up in the UK since the Great Recession and has not returned to pre-recession levels. Despite a rise in happiness there has been a marked increase in anxiety and depression since around 2014 and a rise in people's expectations about unemployment even as the unemployment rate continued to drop. We find a big rise in depression among the underemployed in recent years.

In previous work, we have focused on the extent of underemployment, the characteristics of the underemployed (Bell and Blanchflower, 2011, 2013, 2014, 2018a, 2019), and most recently on its role in wage determination (Bell and Blanchflower, 2018b). We have shown that underemployment increased sharply (and overemployment decreased) at the start of the Great Recession in 2008 across much of Europe. In the UK, underemployment had not returned to its pre-recession level at the beginning of 2018, even though unemployment rate was at a 50-year low. We have also shown that the underemployed are typically young, less well-qualified and poorly paid. Finally, arguing that the existence of slack on the internal labor market reduces pressure on employers to increase pay rates (Bell and Blanchflower 2018b), we have shown that since the Great Recession measures of underemployment enters wage equations significantly negatively for the UK, whereas the unemployment rate is insignificant. We find similar results for the USA (Bell and Blanchflower, 2019).

Conventional supply models predict that workers who do not their desired wage rate and hours combination suffer a welfare loss. This paper extends our previous work on both underemployment and overemployment. We show that welfare loss can be evidenced using a number of indicators of well-being, such as life satisfaction, self-worth and depression. We use the UK Annual Population Survey (APS) which has combined measures of well-being with data on workers' hours preferences. This unlikely combination has been in place since the UK Prime Minister, David Cameron, decided to try to deflect attention from the UK's poor economic performance and instead focus on its wellbeing. We also compare well-being across different labor market states. It turns out that the underemployed are especially unhappy: less so than the unemployed and disabled but more so than any other group of workers. This is true controlling for their lower wage. The overemployed are also less happy than those who are content with the combination of hours and pay on offer.

Classical supply models predict that workers who do not find a job which matches their desired combination of wage rate and hours will suffer a welfare loss. However, this prediction sits rather oddly with the observation that workers' weekly hours tend to cluster around particular values such as 38 or 40. In practice, following Lewis (1969), one can think of observed combinations of wage rates and hours as a compromise between workers' willingness to supply labor and firms' demand preferences. In these circumstances, various elements of the employment bargain may be set by "custom and practice" to reduce negotiation costs. Thus, rather than negotiate separately with each employee, firms find it efficient to set hours of work and pay rates for all workers through negotiation with worker representatives. Production constraints may also make it efficient for employers to insist on some uniformity on working time across the workforce. Further, when faced with fluctuations in demand, employers may respond by varying workers' hours, hoping that 
such variation is temporary (see Oi, 1982). From the employer perspective, this response is generally less costly than varying productive capacity by hiring or firing workers.

Thus, for a variety of reasons, including firm custom and practice and firm response to variations in demand, workers may find themselves "underemployed". Similarly, some may find themselves "overemployed". Whatever the reason, the outcome may be less than ideal from their perspective. And the standard theory would still predict that the greater the gap between the hours that workers would prefer and those that they are offered, the greater their welfare loss. This might be manifest in a number of ways. These might include lower life satisfaction, less happiness, more anxiety, poorer mental health, and possibly poorer physical health. Those who want to work fewer hours may also experience such negative consequences.

In designing policy responses to worker dissatisfaction with working time, it is important to understand how the negative effects of hours deficits on workers compare with effects on those who feel they work too many hours. Thus, one might ask whether those who wish to increase their workweek by, say, four hours experience similar reductions in well-being to those who wish to reduce their working time by four hours? There is no theoretical reason to expect that workers would respond symmetrically to hours deficits and surpluses. This question can only be resolved empirically.

Relatively little is known about who the underemployed or the overemployed are. In this paper we explore the well-being of both groups and find they are relatively unhappy using the APS. It turns out that the underemployed are happier than the unemployed and disabled but less happy than any other group of workers. They are much less happy than either full-timers or voluntary part-timers. The more that actual hours differ from preferred hours, the lower the worker's wellbeing. This is true for those who say they want more hours (the underemployed) and those who say they want less (the over employed).

We also present new evidence that shows a marked rise in depression in the UK since 2014 using the UK Labour Force Survey (LFS) data. This rise is especially marked among the underemployed. The timing seems to match closely the imposition of austerity in the UK in 2010.

\section{The rise in underemployment}

In our previous papers, we examined underemployment in the UK using micro-data (Bell and Blanchflower, 2011, 2013, 2014, 2015, 2018a, 2018b). The data used in this and the previous studies are the quarterly LFS. In this paper, we use LFS data for the period January 2003 to April 2018. Note that the APS and LFS are closely linked: the former uses data combined from two waves of the LFS, but also occasionally collects information on respondent well-being, which makes it ideal, given the subject matter of this paper.

The simplest underemployment variable to construct using the LFS is the involuntary part-time rate using the "part time-wants full-time" (PTWFT) category which is included as one possible response for the variable ftptw. This response is used to construct the UK time series in Chart 1. We express this variable as a proportion of the labour force, which is the same denominator used to calculate the unemployment rate. On the left-hand axis, we plot the unemployment rate and on the right the underemployment rate (PTWFT/labour force). It is notable that the unemployment 
rate in 2018 has returned to pre-recession levels. Indeed, the current rate of $4.2 \%$ in February and March 2018 was last achieved in April 1975. In contrast this underemployment measure has not returned to its pre-recession level. In February 2018, which is the latest data available, the rate was $3.0 \%$ compared with $2.1 \%$ in April 2008, and a series low since 1992 of $1.8 \%$ achieved in eight separate months from April 2004 through January 2005. The underemployment rate suggests lots of labour market slack while the unemployment rate does not.

But benign wage growth seems consistent with the existence of labor market slack, as indicated by the underemployment rate, rather than being absent as per the unemployment rate. ${ }^{1}$ We should note that real wages are still $6 \%$ below their levels at the start of the recession in February $2008 .{ }^{2}$ Nominal wage growth over the period January 2001 through December 2008 averaged 4.2\%; in the period since then it averaged $1.7 \% .^{3}$ Wage growth was clearly higher in the pre-recession period than post-recession and there is little sign of any pick-up since 2015 or so. The much hoped for signs that AWE total pay growth was eventually picking up, with a growth rate of $3.1 \%$ in December 2017 have recently been dashed as the rate fell back to 2.5\% in March 2018. Three months is a long time in economics. This evidence strongly supports the argument that underemployment is now a better predictor of wage growth than is the unemployment rate.

There has also been a marked rise in involuntary part-time employment across advanced countries (Bell and Blanchflower, 2019). It rose during the Great Recession, especially in 2008 and 2009 and has then fallen back. Involuntary part-time rates in 2017 were 5\% or above in Australia; France, Greece, Holland, Japan, New Zealand and Spain. ${ }^{4}$ In the US, where we also have monthly data available, this time on what is called "part-time for economic reasons" (PTER), the latest estimate for May 2018 is 3.1\%, the same as in January 2008. But this series has been as low as $2.2 \%$ in February, April, July and October 2000.

The main exception is Germany where the unemployment rate is only 3.8\% and underemployment is well below pre-recession levels, and wage growth is weak there also. According to the Federal Statistical Office DESTATIS, the change in gross hourly earnings for industry and services for 2017 in Germany was only $2.2 \%$ on the previous year, down slightly from $2.3 \%$ in 2016 . Earnings in 2017Q4 were up 1.9\% while labor costs were up 1.5\% compared with the same quarter a year earlier.

In part the lack of wage growth in Germany seems to be because of the Hartz labor reforms that made the labor market more competitive, and also because of changes in collective bargaining. Rinne and Zimmermann claim that "substantial part of the country's success story during the Great Recession is its recent reform efforts that have helped putting Europe's 'sick man' back on track". In a subsequent paper the same authors, argue that "the German success story is mainly due

\footnotetext{
${ }^{1}$ See also IMF (2017) and Hong et al (2017).

${ }^{2}$ Calculated from the ONS data release a01jun2018.xls, Table 16, using the total pay measure of Average Weekly Earnings (AWE), which the UK's national statistic on wages, in constant 2015 prices. In April 2018 real wages were $£ 490$ versus $£ 522$ in February 2008, or $6.1 \%$ lower.

${ }^{3}$ Calculated by averaging the 'single month' \% change year-on-year by month.

${ }^{4}$ See OECD (2018), chapter 1.
} 
to a combination of structural labor market reforms and the absence of fiscal austerity". 5 Since the 1990s Germany has seen a big decline in union coverage rates, from $83 \%$ in 1995 to $58 \%$ in 2016. This fall has been accompanied by a rise in decentralization of wage setting, from the sectoral to the firm level. Kügler et al (2018) argue that "the low wage growth in Germany .. is in part a consequence of an unprecedented decentralization of the wage setting process". So, the combination of labor market reforms and decentralizing of wage bargaining has meant wage growth has remained contained in Germany despite unemployment rates below 4\%.

\section{The Bell/Blanchflower Underemployment Index}

There is a problem with simply measuring underemployment by looking at part-timers who say they would prefer a full-time job as there is the possibility - and reality - that other groups of workers may be underemployed also. In the US the main measure that is available is to the number of workers who say they are part-time for economic reasons (PTER) which is usually expressed as a proportion of employment or the labor force.

In our earlier papers on underemployment we constructed an underemployment index for the UK for all workers, not just for those who said they were part-time and wanted full-time jobs. We did this for the UK but most recently have been able to construct such an index for other EU countries (Bell and Blanchflower, 2019). Unfortunately, no comparable measure is available for the US.

It turns out that not just part-timers who say they can't find a full-time job (involuntary part-timers) but also part-timers who do not want a full-time job (voluntary part-timers) and full-timers want to change their hours. Other groups of part-timers including students also report wanting more hours. Of importance here is that these reports by workers that they want more hours are at the going wage, not at a higher rate. We should also note that there are also groups of workers, mostly full-timers who say they want fewer hours (the overemployed).

The relevant questions from the UK LFS are.

\section{Q1 PREFHR}

In the job that you were looking for, would you rather work longer hours than in your present job, or would you rather work shorter hours?

\section{Longer}

2 Shorter

3 The same

4 Don't know, no preference

\section{Q2. UNDEMP}

Would you prefer to work longer hours at your current basic rate of pay - that is, not overtime or enhanced pay rates -if you were given the opportunity?

1 yes

2 no

\section{Q3. UNDHRS}

How many extra hours, in addition to those you usually work, would you like to work each week?

${ }^{5}$ Rinne and Zimmermann (2012, 2013). 


\section{Q4. LESPAY}

Would you prefer to work shorter hours than at present in your current job?

1 Yes would still prefer shorter hours

2 No would not prefer shorter hours

Q5. LESPAY2

Would that still be true even if it meant less pay?

Q6. OVHRS UK

How many fewer hours would you like to work in your job?

We are thus able to construct an overhrs (undhrs) variable for those who say they want less (more) hours at the going wage rate. We impose the rule that only those who say they want to change their hours at the going wage rate are counted as desiring to change their hours. Those who wish to increase (decrease) their hours have undhrs (overhrs) set to zero. If individuals express no preference to change their hours, all three variables are set to zero, which seems non-controversial.

Questions over hours preferences are asked of all workers, not just of those who are PTWFT. This potentially matters because the data suggests that less than a third of aggregate desired increases in hours come from those who are PTWFT. In the US, only PTER is available from the Current Population Survey, so it is not possible to measure desired increases or decreases in hours, and therefore impossible to assess the contribution of PETR to aggregate changes in desired hours.

We have used these nationally representative data to construct an underemployment rate each quarter from 2001Q2-2017Q4. We do so by counting the number of hours of those who want more hours and deducting the numbers who want fewer hours and then making unemployment equivalents by dividing through by average hours in the quarter from the LFS data file. Chart 2 plots the aggregates using the sample weights in millions of hours of those who say they want more versus those who want less. Two things stand out. First, in the pre-recession period there was overemployment, because the number of hours of those wanting fewer hours was greater than those numbers wanting more hours. That switched in 2008 as the gap subsequently widened. In the most recent data the gap has narrowed. Chart 4 shows how these numbers translate into an underemployment rate, which in the years before 2008 was below the unemployment rate. These data suggest that, based on the underemployment rate, significant slack still remains in the UK labor market.

We show in Bell and Blanchflower (2018b) that elevated levels of underemployment explain the weakness of wage growth. We find that in a region*year panel dataset, that the unemployment rate has not been a good predictor of wage increases since the Great Recession, whereas increased willingness to work more hours at the going wage rate is a much better predictor of weak wage growth. We now move on to establish who the underemployed are and then to examining their well-being using both involuntary part-time and hours measures of underemployment and overemployment.

\section{Who are the underemployed and the overemployed?}

Tam (2010) from the ONS noted that underemployment "was more prevalent in the part-time than full-time workforce and in those whose usual weekly hours were fewer than 30 hours a week. Compared to their older counterparts, younger people, particularly 16 to 17 year old males, were 
more likely to be underemployed. In both the part-time and full-time workforce, men were more likely than women to be underemployed. Underemployment was also more common in people with lower levels of qualifications, people working in the 'distribution, hotels and restaurants' industry, and employed in 'elementary' occupations. Due to their insufficient hours, the underemployed also earned less income than those who were adequately employed or overemployed." (p.19).

The distribution of labour force status between five types of part-time worker, including PFWT by gender in the LFS data is presented below. On average PTWFT want more hours, but so do other groups including some full-timers. The additional desired hours, averages 1.25 hours per week across all types of worker. Given current employment in March 2018 of 32,394,000 is an additional 40 million hours, which at the months average actual hours worked of 31.8 hours, amounts to around one and a quarter million job-equivalents. ${ }^{6}$

The (weighted) distribution for the period January 2017-April 2018, which is the most recent data available is as follows.

\begin{tabular}{lcccccc} 
& \multicolumn{2}{c}{ Overall \% } & \multicolumn{2}{c}{ Mean under hours } & \multicolumn{2}{c}{ Mean over hours } \\
& Male & Female & Male & Female & Male & Female \\
PT- student & 2.7 & 4.1 & 3.3 & 2.5 & 0.2 & 0.1 \\
PT - ill or disabled & 0.5 & 1.1 & 3.8 & 2.3 & 0.3 & 0.5 \\
PT - wants FT job & 2.7 & 3.9 & 11.0 & 8.7 & n/a & n/a \\
PT voluntary & 6.9 & 32.2 & 1.8 & 1.7 & 0.6 & 0.5 \\
PT no reason given & 0.2 & 0.3 & 3.8 & 3.5 & 0.2 & 0.3 \\
Full-time & 86.9 & 58.2 & 0.6 & 0.5 & 1.2 & 1.6 \\
All & 100 & 100 & 1.0 & 1.3 & 1.1 & 1.1
\end{tabular}

It is appropriate to examine the characteristic of the underemployed and the overemployed as well as their (log) earnings. We merged APS data from several data releases, giving us information on 845,121 individuals and 476,473 workers from January 2013 through April 2018.

The first column of Table 1, which is for workers only, reports the results of estimating a probit equation where the dependent variable is one if the worker is PTWFT and zero otherwise. The main findings are that those employed part-time who would like a full-time job are likely to be young, under the age of thirty. There are also significantly more likely to be female, those without a degree; foreigners; non-whites; those living in the North East and Northern Ireland; in the private sector and in the service sector, especially Other Services and Distribution.

Column 2 estimates the number of additional hours workers want, with those who want no change or less hours set to zero. We also include the worker's labour market status, including whether they were PTWFT. It is apparent that those who were PTWFT were especially likely to want a higher number of additional hours, in fact nine more than full-timers, but each of the other groups want additional hours. Just as with the PTWFT equation, the young want more hours, as do those without a degree; the foreign born, non-whites, those working in the service sector or the private sector. There is much less variation across regions than in the first equation. Males want more

\footnotetext{
${ }^{6}$ Exactly $=1,276,725$ additional workers.
} 
hours, even though they were less likely to be PTWFT, in part, as can be seen below reflecting presumably the fact that a smaller proportion of men $(13 \%)$ than women $(42 \%)$ work part-time.

Column 3 models the number of hours workers say they would like to reduce their work week by. This is something that men, whites; full-timers and older workers want to do. It is especially important in agriculture. It is a phenomenon especially of those with a degree, many of whom presumably, like the authors of this paper, do not have fixed hour contracts.

Finally, in column 4 we estimate an hourly earnings equation, in levels using OLS. It shows that those who are PTWFT have significantly lower wages. Low paid workers want more hours. There is an opposite effect from those who wish to reduce their hours: the over hours variable is positive and significant, suggesting that these workers are paid a compensating differential - to compensate them for working longer than they would wish.

\section{Well-being}

We now turn to examining the well-being of underemployed workers in comparison with other groups of workers as well as the unemployed and those who are out-of-the labor-force (OLF). The APS contains four unique questions we can use to assess well-being. These are:

Q. Next, I would like to ask you four questions about your feelings on aspects of your life. There are no right or wrong answers. For each of these questions I'd like you to give an answer on a scale of nought to 10, where nought is 'not at all' and 10 is 'completely'.

1. Overall, how satisfied are you with your life nowadays?

2. Overall, to what extent do you feel that the things you do in your life are worthwhile?

3. Overall, how happy did you feel yesterday?

4. On a scale where nought is 'not at all anxious' and 10 is 'completely anxious', overall, how anxious did you feel yesterday?

The correlation between these measures was actually rather low. The highest of .59 being between happiness and satisfaction.

$\begin{array}{lrrrr} & \text { Anxious } & \text { Happy } & \text { Satisfied } & \text { Worthwhile } \\ \text { Anxious } & 1.0000 & & & \\ \text { Happy } & -.4717 & 1.0000 & & \\ \text { Satisfied } & -.3518 & .5911 & 1.0000 & \\ \text { Worthwhile } & -.2678 & .5181 & .6504 & 1.000\end{array}$

Table 2 reports average well-being scores, by labor force status and by the numbers of desired under and over hours reported. ${ }^{7}$ The first thing to note is the unemployed and the sick have

\footnotetext{
${ }^{7}$ The ONS reports well-being estimates in a series of publications. 'Personal well-being estimates by age and sex' https://www.ons.gov.uk/peoplepopulationandcommunity/wellbeing/datalist?filter=datasets
} 
especially low levels of well-being, but so too do the PTWFT on all four measures. They are especially unhappy if they are PTWFT and want 20 or more additional hours of work. Those who have too many hours work also show lower levels of wellbeing. There is considerable uniformity across the four measures, noting that a higher score on anxious implies lower well-being. Table 3 shows the four well-being variables by age and each is supportive of an inverted U-shape in wellbeing. Happiness, life satisfaction and worthwhileness minimize in the age range 50-54 while the anxiety variable reaches a maximum in that age band. That is consistent with the findings of a Ushape in happiness and well-being across many countries including the UK in Blanchflower and Oswald (2008, 2018). Blanchflower and Oswald (2008) also report an inverted U-shape in age for the prevalence of depression using LFS data for 2004-2007. This prevalence reaches a maximum in the mid-forties. Finally, Blanchflower and Oswald (2016) find an inverted U-shape across countries in the consumption of anti-depressant medications. See also Rauch (2017).

Table 4 shows that happiness, life satisfaction and worthwhileness have grown steadily over time. In contrast, anxiety, which is shown in the final column, declined from 3.13 in April 2011- March 2012 to a low of 2.83 in October 2014 - September 2015. ${ }^{8}$ Subsequently it has risen despite the continuing fall in unemployment. This finding is consistent with a fear of unemployment dataset published monthly for the UK by the EU Commission. Respondents are asked what they think will happen to unemployment over the next twelve months and a score is created. The series is plotted in Chart 4, which shows a big rise in 2008 and then a subsequent fall back through the middle of 2014. The series then picks up despite the fact that, as is apparent from Chart 1, the unemployment rate continued to fall sharply. The rise in well-being in the UK

If we look at data from the World Database of Happiness comparable data is available using a four-step life satisfaction variable in the UK and all other EU countries. ${ }^{9}$

Question How satisfied are you with the life you lead?

- very satisfied $=4$

- fairly satisfied $=3$

- not very satisfied $=2$

- not at all satisfied $=1$

The table below shows most countries saw little growth over these years. The main exceptions are Greece, Spain and Portugal that saw declines in the unemployment rates.

$\begin{array}{llrr} & 2014 & 2016 & 2017 \\ \text { France } & 3.03 & 3.03 & 3.02 \\ \text { Germany } & 3.19 & 3.20 & 3.24 \\ \text { Greece } & 2.19 & 2.13 & 2.24 \\ \text { Italy } & 2.66 & 2.66 & 2.67 \\ \text { Netherlands } & 4.08 & 4.05 & \mathrm{n} / \mathrm{a} \\ \text { Portugal } & 2.42 & 2.64 & 2.77\end{array}$

${ }^{8}$ See ONS Measuring National Well-being: Anxiety

https://www.ons.gov.uk/peoplepopulationandcommunity/wellbeing/datasets/measuringnationalwellbeinganxiety

${ }^{9}$ https://worlddatabaseofhappiness.eur.nl/hap_nat/nat_fp.php?mode=1 


$\begin{array}{llll}\text { Spain } & 2.84 & 2.91 & 3.01 \\ \text { Sweden } & 3.46 & 3.43 & 3.42 \\ \text { UK } & 3.34 & 3.39 & 3.37\end{array}$

\section{Evidence on the well-being of the underemployed}

There have been some previous studies of underemployment and well-being. For the UK. Kamarade and Richardson (2018) use APS data for 2012-2013 and examine whether involuntary part-timers have lower well-being in the UK. They find that well-being is not significantly lower for men with under one year of tenure for happiness, life satisfaction or anxiety and only for women with short tenure in life satisfaction. The sample sizes here though are small, with around 4000 observations. For those with tenure over a year they find significant negative effects for men only in life satisfaction and for women in both happiness and life satisfaction. One difficulty with this analysis is that women are more likely to be part-time than men.

Heyes et al (2017) examined the 2006 and 2012 Skills and Employment Survey in Britain and measured who measured well-being along 'enthusiasm-depression' and 'contentment-anxiety' axes. They showed lower scores on the scales if workers were dissatisfied with the working time on offer. This includes both working too few, or too many, hours. They also found there was a decline in well-being between 2006 and 2012 as recession hit. Their main finding though is that "workers who are underemployed experience lower well-being levels than those who are more adequately employed". (p.84).

Angrave and Charlwood (2015), make use of longitudinal data from waves 1 to 18 of the British Household Panel for working age adults from 18-65. The question used is similar to the one used in the LFS: 'Think about the hours you work, assuming that you would be paid the same amount per hour, would you prefer to work fewer hours, more hours, or the same number of hours?". They also find that overemployment and underemployment are associated with lower well-being. In job satisfaction; life satisfaction and regressions and a GHQ score that include people fixed effects they find underemployment lowers well-being as does overemployment. Well-being falls if there is a mismatch between actual and preferred hours; long working hours in themselves are not associated with lower subjective well-being.

Wilkins (2007) examined longitudinal data from the 2001 Household, Income and Labour Dynamics in Australia (HILDA) survey and found that underemployment is associated with lower life and job satisfaction. Indeed, he found that well-being losses for part-time workers seeking full-time employment 'are, for some outcomes, not far short of those attributable to unemployment'. Wooden, Warren and Drago (2009) also find for Australia using the HILDA data that underemployment lowers job and life satisfaction.

There is some evidence also on the consequences of underemployment. The concern is that statistical associations between underemployment and health may result from any of the following underlying causal conditions: (1) underemployment affects health; (2) health affects the probability that a person will be underemployed; and (3) an unmeasured third variable affects both underemployment and health (Zapf, Dormann and Frese, 1996). 
Dooley et al (2000) analyzed panel data from the National Longitudinal Survey of Youth for the years 1992-1994 for the 5,113 respondents who were adequately employed in 1992. Controlling for prior depression, shifts from adequate employment to underemployment resulted in significant increases in depression. These direct effects they found, which were similar to moving from employment to unemployment persisted despite inclusion of such potential mediators as changes in income, job satisfaction, and marital status. Prior depression did not predict higher risk of becoming inadequately employed but did predict increased risk of unemployment, particularly for those with less education.

Prause and Dooley (1997) found that underemployment lowered self-esteem, while Dooley and Prause (1998) found it led to increases in symptoms of alcohol abuse. Friedland and Price (2003) find, using longitudinal data for the US from the Americans Challenging Lives Study from 19861994, that underemployed workers report lower levels of health and well-being than adequately employed workers.

Table 5 now moves on to model the four well-being measures using the APS. ${ }^{10}$ This table includes individuals who are both inside and outside the labor force. It identifies those who are PTWFT as well as those who are unemployed; retired; students; home-makers and sick/disabled and residual categories as well as the five part-time categories. The excluded category is full-time employment.

In every case the unemployed and the OLF sick or disabled have low levels of well-being. Other standard results are found including an inverted U-shape in age and higher well-being levels of the self-employed. Christians and the married; students; the retired; whites and the foreign born and those living in Northern Ireland are especially happy, satisfied, think their lives are worthwhile and are less anxious. Males are less happy in the first three columns but also less anxious.

In all four equations the PTWFT have low well-being levels, presumably driven by the low hourly wage and the fact that they can't get enough hours. Of interest is that the voluntary part-timers who do not want a full-time job are happier than full-timers and much happier than those who are stuck in part-time employment. The New Economic Foundation (2012) found similarly in its analysis of well-being using the same well-being measures using the April 2011- March 2012 APS (p.23).

In Table 6 we restrict the sample to workers only and drop the potentially endogenous marital status and religion variable. We add controls for years of tenure; the numbers of under or over hours desired and hourly pay. The results go through. There are U-shapes in age again. The PTWFT are less happy than full-timers or voluntarily chose to be part-timers. Blacks are unhappy. Longer tenure makes workers happy as does higher pay. Of note is that the number of over or under hours the lower the levels of well-being in all four equations. The underemployed and the overemployed are both unhappy. Note that a one-hour desired increase in working time has approximately the same negative effect on happiness and anxiety as does a one-hour desired reduction in working time. However, life satisfaction and seeing life as worthwhile are much more sensitive to those who wish to increase their hours, than those who seek a reduction in hours.

\footnotetext{
${ }^{10}$ Kamarade and Richardson (2018) also used data from the 2012-2013 APS to examine the well-being of the involuntary part-time and found that for employees with longer tenures, underemployment has more negative relationships with the subjective well-being of women than with that of men.
} 
In the quarterly Labour Force Surveys since 1997, respondents were asked to report their main health problem, if they have any. We examined data from January 2014 to March 2018, which has 1,317,412 observations on those age sixteen and over. Overall $63 \%$ say they have none. Two options are available that relate to mental health - a) depression or bad nerves, which accounts for $2.9 \%$ of the total and b) mental illness, phobia, panics or $1.2 \%$ of the total. They are $2.3 \%$ and $0.5 \%$ of workers respectively and $9.7 \%$ and $4.2 \%$ of the unemployed. It turns out that the underemployed are especially likely to report being depressed, although the direction of causality remains unclear. The weighted distribution of being depressed by characteristics is reported in Table 7, (all using LFS weight=pwt). It is apparent that the underemployed are depressed, with the rates being higher for men than women. The proportion is less than for the unemployed but still well above voluntary part-timers and full-timers for both men and women.

Table 8 shows the rise in depression especially since 2011, after the onset of austerity by the UK Chancellor George Osborne in June 2010. The probability of being depressed rises especially rapidly for the underemployed, for men and especially so for underemployed women. If we look at real wages in the UK between 2008 and April 2018 they are down 6.5\%. It is not surprising then to find that over this same period the incidence of depression among workers has nearly quadrupled while that of the unemployed and those who are OLF has not increased by that much. Of particular note is that the incidence of depression among the underemployed has increased more than fourfold - from $1.1 \%$ in 2008 to $4.8 \%$ in 2018 . The rise in depression matches the rise in the fear of unemployment reported in Chart 5.

Chart 6a plots the probabilities of being depressed overall, for workers and for the underemployed who want at least one more hour of work at the going wage. There are obvious inverted U-shapes overall, for workers, and for the underemployed. There is no such inverted U-shape in over hours for the overemployed who want at least one fewer hour which slopes down in Chart 6b. We have no explanation for this.

The inverted U-shape in age using LFS data on depression, for the period 2004Q2-2007Q1 was first reported in Blanchflower and Oswald (2008). Of note is that the peak of the inverted U-shape in the latest data is around $0.4 \%$ which compares with $0.2 \%$ in their figure 1 for the earlier period. So peak unhappiness has risen as has the overall prevalence of depression.

Of interest is that we pooled the data from the complete years 2004-2007 LFS files and examined how depressed the underemployed were compared to everyone else. Overall, $1.2 \%$ of respondents said they were depressed as did $0.7 \%$ of workers. We then did the same for January 2015 to April 2018 and found the weighted proportions were $3.0 \%$ and $2.5 \%$ respectively. Chart 7 a reports the scatter plot reported as Figure 1 (p. 1744) in Blanchflower and Oswald (2008). Chart $7 \mathrm{~b}$ reports the equivalent for the later period, with both including a best fit polynomial of order 2 . The two graphs look similar: there is an inverted U-shape in age in depression. Both maximize on the midforties. What is notable is that the peak in the second period has approximately double the probability the peak has in the first period, consistent with an approximated doubling in the probability of being depressed. Peak unhappiness in middle age is now more pronounced. Consistent with this evidence Blanchflower and Oswald (2016) found evidence of an inverted Ushape in the taking of anti-depressants. 
A recent article by Baxter et al (2014) has challenged the idea that there has been a rise in mental disorders and argued that it is a 'myth'. They argued first that the rise in the incidence of mental disorders was due to the fact that population had risen. But that can be dealt with simply by using the population as denominator. To clarify, what we observed in Table 8 was that depression as a proportion of the population, and a s a proportion of workers, the unemployed and those who were out of the labor force had risen, so that deals with that problem. They also claimed that changing age structures explained by changing age structures. We find that is also not true in the data for the UK. The rise of depression and anxiety in the UK does not seem to be a myth.

Table 9 reports the probabilities of a worker reporting being depressed, using the STATA procedure probit to estimate the probability if an individual being depressed. Data are presented for 2004-2017 first for workers and then for everyone in our data files ages sixteen and over, with missing values excluded, with broadly similar specifications. Controls are included for age, gender, race, education and region plus fourteen year-dummies. The region controls in column 1 relate to work and in column two to residence. The steady increase in the coefficients on the year dummies confirms the rise in depression over time in both columns, controlling for the age structure.

Depression follows an inverted U-shape in age that maximizes in the age band 40-44 years in both equations. The underemployed are especially likely to be depressed and the probability rises as the number of additional hours they want rises. Of note is that the incidence of depression is markedly lower in London $1.9 \%$ versus $2.8 \%$ nationally in our data for the period 2013-2018 which voted against Brexit (59.9\% for Remain versus $48.1 \%$ nationally), than elsewhere.

There is consistent evidence of a rise in depression in the UK from the Adult Psychiatric Morbidity Survey: Survey of Mental Health and Wellbeing, England, $2014^{11}$ The survey reports that between 2007 and 2014 the proportion of respondents with a 'depressive episode' rose from 3.7\% in 2007 to $4.5 \%$ in 2014 . They saw only a small rise in phobias from $2.2 \%$ to $2.7 \%$. This is similar to the data from the LFS we report above, that also contains information on 'mental illness, phobia, panics' which was another option in relation to an individual's main health problem. That rose only slightly, from $0.7 \%$ in $2004-2007$, to $1.0 \%$ in 2013 and to $1.2 \%$ in $2016-2018$.

Consistent with our evidence the UK Council of Psychiatry reported that anxiety and depression hit a record high in 2017, with part-time workers especially bearing the brunt. Part-timers in their report experienced a rise in anxiety between 2013 and 2017 of a third. ${ }^{12}$

A report from the NHS called Prescriptions dispensed in the Community - Statistics for England, 2006-2016 reported that the total number of anti-depressant drugs dispensed in England was nearly 65 million in 2016, up 108.5\% from its 2006 level of 31 million. $^{13}$

\footnotetext{
${ }^{11}$ https://digital.nhs.uk/data-and-information/publications/statistical/adult-psychiatric-morbidity-survey/adultpsychiatric-morbidity-survey-survey-of-mental-health-and-wellbeing-england-2014

12 Mary Bulman, 'Anxiety and depression among UK workers up nearly a third in four years, figures show', The Independent, $10^{\text {th }}$ October 2017.

${ }^{13}$ Dennis Campbell, 'NHS prescribed record number of antidepressants last year', The Guardian, $29^{\text {th }}$ June 2017.
} 
Jorm et al (2017) report that the increased provision of treatments and antidepressants has not reduced the prevalence of depression, though their main explanation seems to be that the treatments don't work. Indeed, for England they argue that the evidence suggests 'England has had an increasing use of antidepressants, hypnotics and possibly talking treatments since 1993. However, there is no evidence for any decrease in prevalence of disorders or reduction of symptoms in adulthood. If anything, trends are in the opposite direction' (2017, p. 92). Our data is consistent with their finding.

\section{Discussion}

Underemployment is now more significant in the UK than unemployment. Based upon the most recent data there are 1.4 million unemployed and just over 1.0 million workers who say they are part-time for economic reasons. In addition, we calculate based on our estimates for 2017 Q4 using the 37.8 million additional hours we calculate as the sum of all the hours of those who say they would like to increase their hours by. If we use the average actual hours of 31.8 the ONS has reported for March 2018, that is equivalent to another 1,187,000 additional unemployed workers. In the latest data available for March 2018 there are 1,426,000 unemployed with a labor force of $33,810,000$ giving an unemployment rate of $4.2 \%$. Adding these additional underemployed equivalents takes the unemployment rate to $7.7 \%$. No wonder there is benign wage growth. Prior to 2008 the number of underemployed workers calculated in this way was nowhere close to the number of unemployed.

These underemployed workers help to keep wage growth in check. If the UK economy was anywhere close to full-employment firms, as their first por of call, would use up hours that are available from its own workers at the going wage. No hiring costs are involved. They might even start weekend working or a night shift. In fact, it is hard to see what costs there are to a firm from increasing a worker's hours say, by a day a week. Presumably this would be the first response before hiring additional workers who have to be found and trained. There is also a benefit of the devil you know. Elevated levels of underemployment suggest the UK economy is nowhere close to full-employment in the summer of 2018, even though the unemployment rate at the time of writing is $4.2 \%$. It is unlikely to be a coincidence that depression and anxiety started to rise at the same time that austerity was imposed in the UK in June 2010. Over the same period real wages, have also failed to pick up and are now $6.3 \%$ below their peak pre-recession level in February 2008.

The unemployed are unhappy and depressed and so are the underemployed. Presumably a large part of this is down to the loss of earnings and lower living standards it implies. We find evidence that the over-employed are unhappy as they are unable to achieve their (smaller) desired hours. The fear of unemployment is on the rise. We find strong evidence of a rise in depression and anxiety (negative affect) in the last five years that is not matched by declines in happiness measures (positive affect). We find evidence of a large rise in anxiety and depression among the underemployed and especially so for underemployed women. The underemployed don't want to be underemployed. 
Table 1. Who are the underemployed and the overemployed and what is their pay? 2013-2018

\#Over hours

\#Under hours

PT- student

PT - ill or disabled

PT - wants FT job

PT voluntary

PT no reason given

Age 18-19

Age 20-24

Age 25-29

Age 30-34

Age 35-39

Age 40-44

Age 45-49

Age 50-54

Age 55-59

Age 60-64

Age 65-69

Age 70 and over

Male

Degree

North West

Yorkshire \& Humber

East Midlands

West Midlands

East

London

South East

South West

Northern Ireland

Scotland

Wales

Foreign

2014

2015

2016

2017

2018

No answer

Mixed

Indian

Pakistani

Bangladeshi

Chinese PTWFT \#Underhours \#Overhours

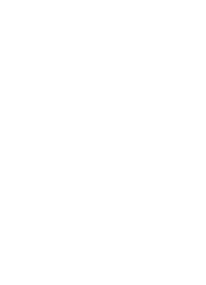

$.6761(16.28)$

.7548 (19.51)

$.4886(12.54)$

$.3102(7.91)$

$.3005(7.66)$

$.3333(8.54)$

$.3612(9.31)$

$.3838(9.90)$

$.4050(10.40)$

$.3875(9.74)$

$.1606(3.57)$

$.0466(0.88)$

$-.1444(19.03)$

$-.2487(28.18)$

$-.0718(4.25)$

$-.0820(4.48)$

$-.1085(5.21)$

$-.0981(5.25)$

$-.1752(8.98)$

$-.0988(5.39)$

- .2243 (12.77)

$-.1272(6.89)$

$.0131(0.49)$

$-.0497(2.97)$

$-.0073(0.42)$

$.1839(15.78)$

$-.0404(3.29)$

$-.0864(7.64)$

-.1351 (10.70)

$-.1817(16.39)$

-.2025 (12.11)

$.1162(0.54)$

.0387 (1.07)

$.0477(2.00)$

$.3869(15.07)$

.5333 (14.36)

$.0306(0.60)$
$2.1033(47.93)$

$9.2442(298.46)-1.1994(37.50)$

$1.4678(90.20) \quad-1.2639(74.73)$

$3.9674(31.31) \quad-1.4013(10.82)$

$1.1157(15.66)$

$1.0198(15.33)$

$.5997(8.84)$

$.3468(5.12)$

$.2724(4.02)$

$.2959(4.38)$

$.2542(3.78)$

$.0936(1.39)$

$-.0726(1.07)$

$-.4956(7.18)$

$-.9638(13.03)$

$-1.2006(14.89)$

$.3897(29.22)$

$-.1774(13.15)$

$-.0026(0.09)$

$.0466(1.48)$

$.0175(0.50)$

$-.0819(2.57)$

$-.0509(1.57)$

$-.0751(2.37)$

$-.0255(0.88)$

$-.0003(0.01)$

$-.2411(5.14)$

$-.0079(0.27)$

$.0486(1.63)$

$.4603(22.64)$

$-.0226(1.05)$

$-.2022(10.32)$

-.2761 (12.89)

$-.2041(10.87)$

$-.2769(10.30)$

$.2729(0.74)$

$.1657(2.61)$

$-.0148(0.37)$

$.3089(5.92)$

$.0857(0.96)$

$-.2661(2.87)$
$.0426(0.58)$

$-.0358(0.52)$

$.1487(2.12)$

$.4460(6.37)$

$.5948(8.49)$

$.6720(9.61)$

$.8721(12.52)$

$1.2027(17.26)$

$1.6701(23.84)$

$1.9453(27.26)$

$1.9406(25.33)$

$1.5146(18.14)$

$-.4055(29.26)$

.3765 (26.85)

$-.0006(0.02)$

$.1092(3.34)$

$.0950(2.60)$

$-.0025(0.08)$

$-.0121(0.36)$

$-.0631(1.91)$

$.0596(1.98)$

$.0602(1.86)$

$-.2428(4.97)$

$-.0146(0.49)$

$.0143(0.46)$

$-.3526(16.69)$

$.0651(2.92)$

$.0224(1.10)$

$-.0029(0.13)$

$.0701(3.59)$

$.0034(0.12)$

$-.2892(0.75)$

$.1135(1.72)$

$-.2024(4.85)$

$-.3391(6.26)$

$.0004(0.00)$

$.0398(0.41)$
Log Hourly Pay

.0034 (15.65)

-.0067 (27.57)

$-.0186(2.63)$

-.2427 (22.06)

-.1813 (32.58)

-.1099 (41.99)

$-.1443(6.31)$

.1615 (14.29)

$.2987(28.41)$

$.4660(43.58)$

$.6064(56.82)$

$.6956(65.14)$

$.7418(69.51)$

$.7536(70.89)$

$.7406(69.64)$

$.7107(66.42)$

$.6610(60.43)$

$.6400(52.70)$

$.5739(39.66)$

$.1411(67.24)$

.4067 (92.11)

$.0259(5.85)$

$.0125(2.63)$

$.0204(3.80)$

.0308 (6.21)

.1101 (21.83)

$.2587(51.83)$

.1514 (34.15)

.0531 (11.19)

$-.0283(3.42)$

$.0640(14.41)$

$.0029(0.64)$

-.1082 (33.39)

$-.0153(2.02)$

$-.0042(0.57)$

$.0167(2.21)$

$.0412(5.57)$

.0525 (6.61)

.0704 (1.09)

$-.0103(1.04)$

$-.0231(3.53)$

$-.1827(19.17)$

$-.1691(10.80)$

.0244 (1.61) 


$\begin{array}{lllll}\text { Other Asian } & .1960(6.29) & .2464(3.95) & -.1366(2.11) & -.0980(9.63) \\ \text { Black } & .2614(12.29) & .5453(13.01) & -.2269(5.21) & -.1336(19.88) \\ \text { Race - other } & .2790(10.27) & .1835(3.32) & -.0988(1.72) & -.0801(8.77) \\ \text { Private sector } & .0271(2.59) & .1011(5.81) & .0175(0.97) & -.0943(34.77) \\ \text { Energy \& Water } & -.3259(5.41) & -.1050(1.57) & -.1405(2.02) & .4179(30.18) \\ \text { Manufacturing } & -.1747(4.03) & -.0051(0.10) & -.3277(5.74) & .3101(24.62) \\ \text { Construction } & -.0294(0.67) & .0064(0.11) & -.2715(4.65) & .3250(25.02) \\ \text { Distribution, hotels etc. } & .5875(14.42) & .2908(5.41) & -.2435(4.36) & .0989(7.92) \\ \text { Transport \& comm. } & .1738(4.10) & .0609(1.10) & -.2950(5.11) & .3262(25.70) \\ \text { Banking \& Finance } & .2074(5.01) & .0433(0.80) & -.2555(4.55) & .3564(28.45) \\ \text { Public administration } & .2762(6.67) & .1291(2.37) & -.3157(5.57) & .1956(15.59) \\ \text { Other services } & .4800(11.36) & .4029(7.01) & -.4607(7.71) & .1280(9.79) \\ \text { Constant } & 2.2182 & .0275 & .9906 & 1.43055 \\ & & & & \\ \text { N } & 472,882 & 470,582 & 472,880 & 265,019 \\ \text { Pseudo/Adjusted R }{ }^{2} & .0700 & .1123 & .0333 & .3424\end{array}$

Notes: equation 1 is a probit the remainder are OLS. Excluded categories; 2013; white; fulltime; North-East. Column 4 is employees only. 
Table 2. Well-being by age and gender, UK, October 2016 - September 2017.

$\begin{array}{lcccc} & \text { Happiness } & \text { Satisfaction } & \text { Worthwhile } & \text { Anxiety } \\ \text { Sex } & & & & \\ \text { Male } & 7.50 & 7.67 & 7.76 & 2.75 \\ \text { Female } & 7.54 & 7.72 & 7.07 \\ \text { Age group } & & & 7.69 & 2.82 \\ 16 \text { to } 19 & 7.61 & 7.86 & 7.82 & 3.04 \\ 20 \text { to } 24 & 7.41 & 7.74 & 7.91 & 2.88 \\ 25 \text { to } 29 & 7.49 & 7.76 & 7.90 & 2.92 \\ 30 \text { to } 34 & 7.53 & 7.75 & 7.84 & 3.04 \\ 35 \text { to } 39 & 7.44 & 7.65 & 7.77 & 3.05 \\ 40 \text { to } 44 & 7.41 & 7.55 & 7.76 & 3.09 \\ 45 \text { to } 49 & 7.32 & 7.47 & 7.83 & 3.10 \\ 50 \text { to } 54 & 7.30 & 7.46 & 7.94 & 3.06 \\ 55 \text { to } 59 & 7.39 & 7.51 & 8.13 & 2.90 \\ 60 \text { to } 64 & 7.58 & 7.69 & 8.20 & 2.57 \\ 65 \text { to } 69 & 7.86 & 7.96 & 8.06 & 2.63 \\ 70 \text { to } 74 & 7.89 & 7.99 & 7.90 & 2.57 \\ 75 \text { to } 79 & 7.82 & 7.91 & 7.72 & 2.61 \\ 80 \text { to } 84 & 7.75 & 7.84 & 7.31 & 2.69 \\ 85 \text { to } 89 & 7.62 & 7.72 & & 2.76 \\ 90 \text { and } \text { over } & 7.45 & 7.52 & & \end{array}$

Source: Annual Population Survey, Office for National Statistics

https://www.ons.gov.uk/peoplepopulationandcommunity/wellbeing/datasets/personalwellbeingestimatesbyageandsex 
Table 3. Changes in well-being over time

$\begin{array}{lcccc} & \text { Happy } & \text { Satisfaction } & \text { Worthwhile } & \text { Anxious } \\ \text { April 2011 - March 2012 } & 7.29 & 7.42 & 7.67 & 3.13 \\ \text { July 2011 - June 2012 } & 7.29 & 7.43 & 7.68 & 3.08 \\ \text { October 2011 - September 2012 } & 7.30 & 7.45 & 7.69 & 3.05 \\ \text { January 2012 - December 2012 } & 7.31 & 7.45 & 7.70 & 3.03 \\ \text { April 2012 - March 2013 } & 7.30 & 7.46 & 7.70 & 3.03 \\ \text { July 2012 - June 2013 } & 7.33 & 7.48 & 7.71 & 3.00 \\ \text { October 2012 - September 2013 } & 7.35 & 7.49 & 7.72 & 2.96 \\ \text { January 2013 - December 2013 } & 7.37 & 7.49 & 7.73 & 2.95 \\ \text { April 2013 - March 2014 } & 7.39 & 7.51 & 7.74 & 2.92 \\ \text { July 2013 - June 2014 } & 7.42 & 7.54 & 7.76 & 2.91 \\ \text { October 2013 - September 2014 } & 7.43 & 7.56 & 7.78 & 2.91 \\ \text { January 2014 - December 2014 } & 7.44 & 7.58 & 7.80 & 2.89 \\ \text { April 2014 - March 2015 } & 7.46 & 7.61 & 7.82 & 2.86 \\ \text { July 2014 - June 2015 } & 7.48 & 7.63 & 7.84 & 2.84 \\ \text { October 2014 - September 2015 } & 7.48 & 7.65 & 7.84 & 2.83 \\ \text { January 2015 - December 2015 } & 7.48 & 7.65 & 7.84 & 2.85 \\ \text { April 2015 - March 2016 } & 7.48 & 7.65 & 7.84 & 2.87 \\ \text { July 2015 - June 2016 } & 7.46 & 7.65 & 7.84 & 2.89 \\ \text { October 2015 - September 2016 } & 7.48 & 7.66 & 7.84 & 2.90 \\ \text { January 2016 - December 2016 } & 7.49 & 7.67 & 7.85 & 2.89 \\ \text { April 2016 - March 2017 } & 7.51 & 7.68 & 7.86 & 2.90 \\ \text { July 2016 - June 2017 } & 7.52 & 7.69 & 7.87 & 2.91 \\ \text { October 2016 - September 2017 } & 7.52 & 7.69 & 7.87 & 2.92 \\ \text { January 2017 - December 2017 } & 7.53 & 7.69 & 7.88 & 2.91\end{array}$

Source: ONS Personal Well Being Estimates, January 2017-December 2017 https://www.ons.gov.uk/peoplepopulationandcommunity/wellbeing/datasets/headlineestimatesof personalwellbeing 
Table 4. Well-being by labor force status and \# under and over hours, January 2013-January 2017. $\mathrm{N}=357,909$

$\begin{array}{lcccc} & \text { Happy } & \text { Satisfied } & \text { Worthwhile } & \text { Anxious } \\ \text { Part-time - student } & 7.40 & 7.76 & 7.87 & 3.02 \\ \text { Part-time: ill or disabled } & 6.56 & 6.68 & 7.40 & 4.04 \\ \text { PTWFT } & 7.22 & 7.18 & 7.55 & 3.11 \\ \text { Part-time DNWFT } & 7.67 & 7.85 & 8.17 & 2.80 \\ \text { Part-time no reason } & 7.45 & 7.31 & 8.00 & 3.19 \\ \text { Full-time } & 7.47 & 7.69 & 7.89 & 2.82 \\ \text { Unemployed } & 6.92 & 6.67 & 7.12 & 3.40 \\ \text { OLF other } & 7.43 & 7.44 & 7.68 & 2.98 \\ \text { Retired } & 7.81 & 7.91 & 8.00 & 2.59 \\ \text { Student } & 7.50 & 7.78 & 7.88 & 3.01 \\ \text { Homemaker } & 7.49 & 7.58 & 8.08 & 2.92 \\ \text { Sick/disabled } & 5.88 & 5.80 & 6.31 & 4.64 \\ & & & & \\ \text { Workers only } & & 7.75 & 7.96 & 2.80 \\ \text { Under hours }=0 & 7.52 & 7.56 & 7.90 & 3.16 \\ \text { Under hours 1-4 } & 7.49 & 7.52 & 7.83 & 3.12 \\ \text { Under hours 5-9 } & 7.40 & 7.30 & 7.69 & 3.17 \\ \text { Under hours 10-19 } & 7.27 & 6.99 & 7.44 & 3.29 \\ \text { Under hours } \geq 20 & 7.12 & 6.79 & 7.18 & 3.19 \\ \text { PTWFT under hours }>10 & 7.00 & & & \\ & & 7.70 & 7.94 & 2.81 \\ \text { Over hours=0 } & 7.51 & 7.76 & 7.85 & 3.11 \\ \text { Over hours 1-4 } & 7.37 & 7.69 & 7.84 & 3.16 \\ \text { Over hours 5-9 } & 7.35 & 7.72 & 7.92 & 3.12 \\ \text { Over hours 10-19 } & 7.42 & & 7.84 & 3.29 \\ \text { Over hours } \geq 20 & 7.25 & 7.70 & 7.93 & 2.84 \\ & & & & \end{array}$


Table 5. OLS Well-being regressions, UK January 2013-January 2017

\begin{tabular}{|c|c|c|c|c|}
\hline & Happiness & Satisfaction & Worthwhile & Anxious \\
\hline 2014 & $.0662(6.19)$ & $.0646(7.37)$ & $.0626(7.35)$ & $-.0172(1.19)$ \\
\hline 2015 & $.1019(10.46)$ & $.1380(17.28)$ & $.1039(13.40)$ & $-.0785(5.98)$ \\
\hline 2016 & $.1131(10.83)$ & $.1496(17.48)$ & $.1232(14.81)$ & $-.0690(4.91)$ \\
\hline 2017 & $.0760(1.47)$ & $.0947(2.23)$ & $.0945(2.29)$ & $-.1074(1.54)$ \\
\hline Age & $-.0228(16.19)$ & $-.0413(35.73)$ & $-.0071(6.33)$ & $.0340(17.91)$ \\
\hline $\mathrm{Age}^{2}$ & $.0002(15.62)$ & $.0003(31.83)$ & $.0000(5.10)$ & $-.0002(15.51)$ \\
\hline Male & $-.0378(4.98)$ & $-.0769(12.36)$ & $-.2248(37.19)$ & $-.3348(32.72)$ \\
\hline Degree & $.0428(4.74)$ & $.0490(6.63)$ & $.0723(10.06)$ & $.1369(11.24)$ \\
\hline Self-employed & $.1080(8.06)$ & $.0466(4.25)$ & $.1436(13.48)$ & $-.0188(1.05)$ \\
\hline North West & $-.0230(1.35)$ & $-.0553(3.95)$ & $-.0001(0.01)$ & $-.0096(0.42)$ \\
\hline Yorks \& Humber & $.0194(1.05)$ & $-.0061(0.41)$ & $.0352(2.40)$ & $.0466(1.88)$ \\
\hline East Midlands & $.0911(4.35)$ & $.0221(1.29)$ & $.0346(2.08)$ & $-.0441(1.56)$ \\
\hline West Midlands & $.0116(0.62)$ & $-.0321(2.09)$ & $-.0338(2.26)$ & $-.1835(7.24)$ \\
\hline East & $.0289(1.48)$ & $-.0381(2.38)$ & $.0051(0.33)$ & $-.0168(0.64)$ \\
\hline London & $-.0140(0.73)$ & $-.0874(5.57)$ & $-.0829(5.44)$ & $.1377(5.34)$ \\
\hline South East & $.0567(3.30)$ & $.0138(0.99)$ & $.0134(0.98)$ & $-.0076(0.33)$ \\
\hline South West & $.0470(2.56)$ & $.0029(0.19)$ & $-.0012(0.09)$ & $-.0527(2.13)$ \\
\hline Northern Ireland & $.5087(4.55)$ & $.4363(4.79)$ & $.2536(2.86)$ & $-.4118(2.73)$ \\
\hline Scotland & $.1177(7.01)$ & $.1140(8.28)$ & $.0629(4.71)$ & $-.1635(7.22)$ \\
\hline Wales & $.0811(4.69)$ & $.0275(1.95)$ & $.0378(2.75)$ & $-.0025(0.11)$ \\
\hline PT- student & $.0163(0.43)$ & $-.0089(0.29)$ & $.1073(3.54)$ & $.3850(7.49)$ \\
\hline PT - ill or disabled & $-.7400(13.95)$ & $-.8792(20.23)$ & $-.5227(12.39)$ & $.9827(13.75)$ \\
\hline PT - wants FT job & $-.1956(8.02)$ & $-.4525(22.65)$ & $-.3189(16.42)$ & $.2538(7.72)$ \\
\hline PT voluntary & $.1439(12.20)$ & $.0883(9.15)$ & $.1126(12.01)$ & $-.1453(9.15)$ \\
\hline PT no reason given & $.0023(0.02)$ & $-.2434(3.13)$ & $-.0044(0.06)$ & $.0826(0.65)$ \\
\hline Unemployed & $-.4535(22.00)$ & $-.9349(55.38)$ & $-.6486(39.53)$ & .5855 (21.09) \\
\hline Retired & $.3022(20.94)$ & $.2004(16.95)$ & $.0812(7.07)$ & $-.2498(12.85)$ \\
\hline OLF student & $.1282(4.26)$ & $.0424(1.72)$ & $.1648(6.88)$ & $.3464(8.54)$ \\
\hline Home maker & $-.0399(2.32)$ & $-.2212(15.67)$ & $.0753(5.49)$ & $.1022(4.40)$ \\
\hline OLF sick/disabled & $-1.4321(88.80)$ & $-1.6860(27.62)$ & $-1.4816(15.28)$ & $1.7254(79.39)$ \\
\hline OLF other & $.0289(1.23)$ & $-.1648(8.54)$ & $-.1811(9.67)$ & $.0469(1.48)$ \\
\hline Religion $\mathrm{n} / \mathrm{a}$ & $-.1766(1.64)$ & $-.1791(2.04)$ & $-.0218(0.26)$ & $.0846(0.58)$ \\
\hline No religion & $-.1637(19.64)$ & $-.1377(20.17)$ & $-.1945(29.32)$ & $-.0556(4.96)$ \\
\hline Buddhist & $-.0701(1.19)$ & $-.1011(2.09)$ & $-.0620(1.31)$ & $-.0965(1.21)$ \\
\hline Hindu & $-.0858(1.71)$ & $-.1114(2.72)$ & $-.1254(3.14)$ & $.0674(1.00)$ \\
\hline Jewish & $-.1285(2.21)$ & $-.1484(3.11)$ & $-.0624(1.35)$ & $.3279(4.18)$ \\
\hline Muslim & $-.0891-2.52)$ & $.0138(0.48)$ & $-.0089(0.32)$ & $.0376(0.79)$ \\
\hline Sikh & $-.2675(3.95)$ & $-.2668(4.81)$ & $-.2520(4.66)$ & $.0601(0.66)$ \\
\hline Religion other & $-.1281(4.96)$ & $-.1214(5.74)$ & $-.0204(1.00)$ & $.1684(4.84)$ \\
\hline Foreign born & $.0987(7.04)$ & $.0182(1.59)$ & $-.0491(4.39)$ & $-.0450(2.38)$ \\
\hline Married & $.4332(42.42)$ & $.5308(63.46)$ & $.4220(51.93)$ & $-.2170(15.78)$ \\
\hline Separated & $-.2307(11.12)$ & $-.3408(20.05)$ & $-.0765(4.63)$ & $.2544(9.10)$ \\
\hline Divorced & $-.0336(2.41)$ & $-.0613(5.37)$ & $.0196(1.77)$ & $.0021(0.11)$ \\
\hline Widowed & $-.2404(14.28)$ & $-.2479(17.98)$ & $-.1449(10.81)$ & $.0352(1.55)$ \\
\hline
\end{tabular}




$\begin{array}{lcccc}\text { Civil partnership } & .2742(3.91) & .5442(9.46) & .3770(6.76) & .1882(1.99) \\ \text { Race no answer } & -.1243(0.37) & -.0981(0.36) & -.4195(1.58) & -.9097(1.96) \\ \text { Mixed } & -.0618(1.41) & -.1194(3.32) & .0052(0.15) & .1127(1.91) \\ \text { Indian } & .0906(2.10) & -.0343(0.97) & -.0255(0.74) & .0664(1.14) \\ \text { Pakistani } & .0115(0.24) & -.1475(3.70) & -.1554(4.00) & .0418(0.64) \\ \text { Bangladeshi } & -.0002(0.00) & -.1260(2.27) & -.1151(2.13) & .0011(0.01) \\ \text { Chinese } & .0274(0.47) & -.1054(2.18) & -.1351(2.87) & -.1419(1.78) \\ \text { Other Asian } & .0068(0.15) & -.0766(2.00) & -.0946(2.52) & .1139(1.80) \\ \text { Black } & -.1047(3.84) & -.3441(15.41) & -.0631(2.90) & -.1425(3.88) \\ \text { Race }- \text { other } & -.1267(3.30) & -.1401(4.45) & -.1089(3.55) & .1305(2.52) \\ \text { Constant } & 7.7535 & 8.5147 & 7.9820 & 2.2493 \\ \text { N } & 357,741 & 357,884 & 356,798 & 357,927 \\ \text { Adjusted } \mathrm{R}^{2} & .0586 & .1118 & .0830 & .0351\end{array}$

Notes: t-statistics in parentheses. Excluded categories; North East; Christian; single; full-time and 2013. 
Table 6. OLS Well-being regressions for employees, UK January 2014-January 2017

\begin{tabular}{|c|c|c|c|c|}
\hline & Happiness & Satisfaction & Worthwhile & Anxious \\
\hline 2014 & $.0577(3.65)$ & $.0629(5.21)$ & $.0368(3.21)$ & $-.0398(1.82)$ \\
\hline 2015 & $.0817(5.66)$ & $.1072(9.71)$ & $.0797(7.61)$ & $-.1008(5.06)$ \\
\hline 2016 & $.0977(6.26)$ & $.1182(9.91)$ & $.0986(8.72)$ & $-.0601(2.79)$ \\
\hline 2017 & $.1130(1.44)$ & $.0538(0.90)$ & $.0511(0.90)$ & $-.1694(1.56)$ \\
\hline Age & $-.0493(16.49)$ & $-.0732(32.06)$ & $-.0396(18.27)$ & $.0665(16.12)$ \\
\hline $\mathrm{Age}^{2}$ & $.0005(16.95)$ & $.0007(29.45)$ & .0004 (19.39) & $-.0006(14.47)$ \\
\hline Male & $.0061(0.50)$ & $-.0405(4.36)$ & $-.1549(17.56)$ & $-.2925(17.41)$ \\
\hline Degree & $-.0235(1.83)$ & $-.0451(4.59)$ & $-.0204(2.18)$ & $.2470(13.89)$ \\
\hline North West & $-.0080(0.32)$ & $-.0239(1.24)$ & $.0142(0.78)$ & $-.0131(0.38)$ \\
\hline Yorks \& Humber & $-.0043(0.16)$ & $.0050(0.24)$ & $.0117(0.60)$ & $.0266(0.71)$ \\
\hline East Midlands & $.0286(0.94)$ & $-.0200(0.86)$ & $-.0083(0.38)$ & $-.0336(0.80)$ \\
\hline West Midlands & $.0203(0.72)$ & $-.0007(0.03)$ & $-.0121(0.59)$ & $-.1712(4.37)$ \\
\hline East & $-.0114(0.39)$ & $-.0580(2.63)$ & $-.0347(1.66)$ & $.0215(0.54)$ \\
\hline London & $-.0753(2.65)$ & $-.1720(7.91)$ & $-.1613(7.82)$ & $.2230(5.68)$ \\
\hline South East & $-.0199(0.79)$ & $-.0407(2.11)$ & $-.0663(3.62)$ & $.070(2.03)$ \\
\hline South West & $-.0160(0.59)$ & $-.0381(1.83)$ & $-.0517(2.62)$ & $.0144(0.39)$ \\
\hline Northern Ireland & $.4170(8.51)$ & $.2750(7.34)$ & $.2709(7.63)$ & $-.3908(5.78)$ \\
\hline Scotland & $.1009(4.01)$ & $.0964(5.01)$ & $.0475(2.61)$ & $-.1851(5.33)$ \\
\hline Wales & $.0858(3.28)$ & $.0428(2.14)$ & $.0156(0.83)$ & $-.0549(1.52)$ \\
\hline PT- student & $-.0213(0.50)$ & $-.0423(1.30)$ & $.0768(2.49)$ & $.4543(7.73)$ \\
\hline PT - ill or disabled & $-.6762(10.97)$ & $-.7177(15.22)$ & $-.4442(9.93)$ & $.9924(11.65)$ \\
\hline PT - wants FT job & $-.0724(2.39)$ & $-.1699(7.32)$ & $-.1613(7.32)$ & $.0545(1.30)$ \\
\hline PT voluntary & $.1955(13.82)$ & $.1978(18.29)$ & $.1817(17.72)$ & $-.1360(6.96)$ \\
\hline PT no reason given & $.1898(1.50)$ & $-.0186(0.19)$ & $.2052(2.23)$ & $-.1271(0.73)$ \\
\hline Foreign born & .1908 (9.99) & $.0938(6.43)$ & $.0569(4.10)$ & $-.0228(0.86)$ \\
\hline Mixed & $-.0271(0.04)$ & $-.1323(0.25)$ & $-.2666(0.53)$ & $-.2135(0.22)$ \\
\hline Indian & $-.1586(2.69)$ & $-.2223(4.94)$ & $-.1020(2.39)$ & $.2024(2.49)$ \\
\hline Pakistani & $.1524(3.93)$ & $.0179(0.60)$ & $.0534(1.90)$ & $.0944(1.76)$ \\
\hline Bangladeshi & $.1198(2.03)$ & $.0212(0.47)$ & $.0775(1.81)$ & $.0459(0.56)$ \\
\hline Chinese & $.0529(0.57)$ & $-.0316(0.45)$ & $.0483(0.72)$ & $.1794(1.41)$ \\
\hline Other Asian & $-.0455(0.51)$ & $-.3090(4.52)$ & $-.2826(4.33)$ & $-.2090(1.69)$ \\
\hline Black & $.1397(2.24)$ & $.0669(1.40)$ & $.0687(1.51)$ & $.0230(0.27)$ \\
\hline Race - other & $-.2075(5.50)$ & $-.4335(15.03)$ & $-.1106(4.04)$ & $-.0454(0.88)$ \\
\hline Race no answer & $-.0166(0.31)$ & $-.0697(1.71)$ & $.0071(0.19)$ & $.1203(1.63)$ \\
\hline Private sector & $-.1961(2.36)$ & $-.2030(3.20)$ & $-.1593(2.64)$ & $.1823(1.59)$ \\
\hline Energy \& Water & $-.2391(3.14)$ & $-.2035(3.50)$ & $-.2303(4.17)$ & $.1755(1.67)$ \\
\hline Manufacturing & $-.1475(1.87)$ & $-.1312(2.18)$ & $-.1227(2.15)$ & $.0717(0.66)$ \\
\hline Construction & $-.2159(2.86)$ & $-.2582(4.48)$ & $-.2700(4.93)$ & $.1433(1.38)$ \\
\hline Distribution & $-.1676(2.19)$ & $-.2101(3.59)$ & $-.2460(4.42)$ & $.1763(1.67)$ \\
\hline Transport & $-.2000(2.64)$ & $-.2203(3.81)$ & $-.2402(4.37)$ & $.2643(2.53)$ \\
\hline Banking \& Finance & $-.1668(2.20)$ & $-.2135(3.69)$ & $-.0114(0.21)$ & $.2104(2.01)$ \\
\hline Public admin & $-.1139(1.45)$ & $-.1779(2.96)$ & $-.0922(1.62)$ & $.1963(1.81)$ \\
\hline Other services & $-.0159(1.04)$ & $-.0127(1.09)$ & $-.0431(3.89)$ & $-.0036(0.17)$ \\
\hline Years tenure & $.0031(4.77)$ & $.0054(10.75)$ & $.0021(4.38)$ & $-.0009(1.04)$ \\
\hline
\end{tabular}


Wednesday, June 27, 2018 - 11:06:53 AM

$\begin{array}{lcclc}\text { \#Under hours } & -.0121(9.06) & -.0250(24.42) & -.0149(15.34) & .0239(12.97) \\ \text { \#Over hours } & -.0105(8.00) & -.0035(3.45) & -.0064(6.80) & .0237(13.06) \\ \text { Hourly pay } & .1448(12.73) & .2240(25.78) & .1532(18.58) & -.1227(7.82) \\ \text { Constant } & 8.1813 & 8.9628 & 8.5002 & 1.5100 \\ & & & & \\ \mathrm{~N} & 143,607 & 143,620 & 143,607 & 143,620 \\ \text { Adjusted R } & .0101 & .0307 & .0101 & .0307\end{array}$

Notes: t-statistics in parentheses. Excluded categories; North East; Christian; single; full-time and 2014. All equations also include 8 industry dummies 
Wednesday, June 27, 2018 - 11:06:53 AM

Table 7. Proportion depressed, UK, January 2013- March 2018-n=1,624,298

OLF

Homemaker

Student

Retired

Unemployed

Part-time: student

Part-time: ill or disabled

Part-time: could not find full-time job

Part-time: did not want full-time job

Part-time: no reason given

Full-time

Unpaid family worker

All

\section{Workers only}

Employed

Employees

Self-employed

Under hours $=0$

Under hours $>0$

Under hours 1-4

Under hours 5-9

Under hours 10-19

Under hours $\geq 20$

Over hours $=0$

Over hours $>0$

Over hours 1-4

Over hours 5-9

Over hours 10-19

Over hours $\geq 20$
Men

2.8

4.6

1.0

0.8

5.1

1.4

6.0

2.6

1.8

4.0

1.4

1.9

2.0

1.5

1.5

1.3

1.5

2.4

2.2

2.1

2.4

2.7

2.2

1.7

1.7

1.8

1.7

1.5
Women

3.8

5.0

2.4

1.5

7.3

2.7

8.2

4.2

3.1

5.8

2.6

3.2

3.4

3.1

3.0

2.7

2.8

4.3

3.7

4.0

4.4

4.9

3.7

3.0

3.5

3.4

2.7

2.9 
Wednesday, June 27, 2018 - 11:06:53 AM

Table 8. Changes over time in the probability of being depressed, January 1997-April 2018

\begin{tabular}{lll|lcc|cc} 
& All & Workers & \multicolumn{3}{|c|}{ Workers with under hours $>0$} & Unemployed & OLF \\
& & & All & Men & Women & & \\
1997 & 0.6 & 0.2 & 0.3 & 0.2 & 0.4 & 0.8 & 1.2 \\
1998 & 0.8 & 0.3 & 0.4 & 0.3 & 0.5 & 1.2 & 1.5 \\
1999 & 0.8 & 0.3 & 0.5 & 0.5 & 0.6 & 1.7 & 1.6 \\
2000 & 0.9 & 0.3 & 0.6 & 0.4 & 0.7 & 1.5 & 1.8 \\
& & & & & & & \\
2001 & 1.0 & 0.4 & 0.7 & 0.5 & 0.8 & 1.6 & 1.9 \\
2002 & 1.3 & 0.6 & 0.8 & 0.6 & 1.0 & 1.9 & 2.3 \\
2003 & 1.4 & 0.7 & 1.0 & 0.9 & 1.2 & 2.3 & 2.5 \\
2004 & 1.5 & 0.7 & 1.0 & 0.8 & 1.1 & 2.6 & 2.7 \\
& & & & & & & \\
2005 & 1.5 & 0.7 & 1.0 & 0.8 & 1.2 & 2.8 & 2.6 \\
2006 & 1.4 & 0.7 & 1.1 & 0.7 & 1.5 & 2.5 & 2.5 \\
2007 & 1.5 & 0.7 & 1.1 & 0.8 & 1.4 & 2.7 & 2.6 \\
2008 & 1.5 & 0.8 & 1.1 & 0.8 & 1.4 & 2.8 & 2.5 \\
& & & & & & & \\
2009 & 1.5 & 0.8 & 1.3 & 0.9 & 1.6 & 2.4 & 2.5 \\
2010 & 1.6 & 1.0 & 1.5 & 1.0 & 1.9 & 2.9 & 2.5 \\
2011 & 1.7 & 1.0 & 1.4 & 0.9 & 1.8 & 3.4 & 2.6 \\
2012 & 1.9 & 1.9 & 1.9 & 1.4 & 2.3 & 3.8 & 2.7 \\
& & & & & & & \\
2013 & 2.0 & 1.4 & 2.2 & 1.4 & 2.9 & 4.2 & 2.7 \\
2014 & 2.4 & 1.8 & 2.7 & 2.0 & 3.3 & 5.2 & 3.2 \\
2015 & 2.7 & 2.1 & 3.2 & 2.5 & 3.9 & 6.6 & 3.4 \\
2016 & 2.9 & 2.3 & 3.8 & 2.6 & 4.9 & 7.3 & 3.6 \\
& & & & & & & \\
2017 & 3.3 & 2.8 & 4.5 & 3.1 & 5.7 & 7.5 & 3.7 \\
2018 & 3.6 & 3.1 & 4.8 & 3.4 & 6.1 & 8.0 & 3.9
\end{tabular}


Table 9. Probability of workers being depressed (probits), 2004-2018

Age 20-24

Age 25-29

Age 30-34

Age 35-39

Age 40-44

Age 45-49

Age 50-54

Age 55-59

Age 60-64

Age 65-69

Age $>=70$

Male

Age left school

Mixed race

Asian

Chinese

Black

Other race

PT - student

PT - ill or disabled

PT - wants FT job

PT voluntary

PT no reason given

Unpaid family worker

Unemployed

OLF student

OLF homemaker

OLF temp sick

OLF retired

OLF long-term sick

OLF other reason

OLF no reason

\#Under hours

\#Over hours

Rest of North

South Yorkshire

West Yorkshire

Rest Yorkshire \& Humber

East Midlands

East Anglia

Central London

Inner London

Outer London

Rest of South East

$$
\begin{aligned}
& .1696(8.41) \\
& .2298(11.66) \\
& .2430(12.41) \\
& .2550(13.09) \\
& .2830(14.62) \\
& .2507(12.95) \\
& .2084(10.70) \\
& .1190(6.01) \\
& -.0114(0.54) \\
& -.2387(8.75) \\
& -.3527(9.01) \\
& -.1911(40.74) \\
& -.0063-8.58) \\
& .0180(0.76) \\
& -.3857(25.59) \\
& -.4362(8.52) \\
& -.3749(17.46) \\
& -.2105(8.72) \\
& .1665(7.68) \\
& .8047(56.19) \\
& .2356(22.73) \\
& .1196(21.60) \\
& .1562(3.73) \\
& .3530(8.94)
\end{aligned}
$$$$
.0039(14.76)
$$$$
.0061(12.61)
$$$$
-.0775(4.32)
$$$$
.0206 \text { (1.09) }
$$$$
-.0225(1.33)
$$$$
-.0885(4.86)
$$$$
-.0725(4.63)
$$$$
-.0429(2.57)
$$$$
-.2313(12.39)
$$$$
-.1376(7.19)
$$$$
-.1825(10.38)
$$$$
-.0760(5.26)
$$

$$
\begin{gathered}
.2257(15.93) \\
.3051(22.04) \\
.3245(23.66) \\
.3348(24.60) \\
.3592(26.57) \\
.3174(23.40) \\
.2547(18.65) \\
.1078(7.79) \\
-.0741(5.06) \\
-.2972(17.26) \\
-.3271(8.91) \\
-.1412(38.44) \\
-.0119(19.81) \\
.0332(1.82) \\
-.3607(34.96) \\
-.4514(11.30) \\
-.3140(21.09) \\
-.1683(10.45) \\
.1983(9.39) \\
.8358(58.82) \\
.2642(25.85) \\
.1568(29.41) \\
.5771(26.30) \\
.3949(9.96) \\
.6456(81.25) \\
.5274(28.35) \\
.6702(99.55) \\
1.3983(101.53) \\
.5485(49.79) \\
1.2024(205.72) \\
.6008(57.83) \\
.5152(15.00) \\
. .1940(1254(11.23) \\
.0035(13.48) \\
-.0071(14.77) \\
-.0239(1.66) \\
-.0398(3.03) \\
-.1564(10.77) \\
-.1141(9.44) \\
-.0929(7.01) \\
\end{gathered}
$$




$\begin{array}{llc}\text { South West } & -.0677(4.45) & -.1073(9.02) \\ \text { West Midland (Met county) } & -.1013(5.78) & -.0952(7.07) \\ \text { Rest West Midlands } & -.0979(5.79) & -.1384(10.57) \\ \text { Greater Manchester } & -.0827(4.84) & -.0631(4.85) \\ \text { Merseyside } & -.0886(4.31) & -.0826(5.51) \\ \text { Rest North West } & -.1185(6.86) & -.1378(10.30) \\ \text { Wales } & -.0477(2.88) & -.0441(3.52) \\ \text { Strathclyde } & -.0169(0.98) & .0165(1.28) \\ \text { Rest of Scotland } & -.1091(6.61) & -.1203(9.39) \\ \text { Northern Ireland } & -.1814(10.11) & -.0998(7.64) \\ \text { Outside UK } & -.6499(6.53) & n \\ 2005 & .0134(1.03) & -.0452(5.15) \\ 2006 & .0068(0.52) & -.0651(7.29) \\ 2007 & .0346(2.65) & -.0394(4.43) \\ 2008 & .0436(3.31) & -.0333(3.78) \\ 2009 & .0701(5.37) & -.0219(2.50) \\ 2010 & .1337(10.39) & .0120(1.37) \\ 2011 & .1643(12.90) & .0466(5.37) \\ 2012 & .2274(18.34) & .0937(10.94) \\ 2013 & .2859(23.39) & .1456(17.13) \\ 2014 & .3816(32.30) & .2940(30.30) \\ 2015 & .4436(37.91) & .3584(37.47) \\ 2016 & .4867(42.30) & .3989(42.73) \\ 2017 & .5794(52.88) & .4940(57.09) \\ 2018 & .6304(40.88) & .5467(39.48) \\ \text { Constant } & -2.4293 & -2.3110 \\ \text { N } & & 3,488,736 \\ \text { Pseudo R } & & .1005\end{array}$

Notes: equation 1 is workers only. Equation 2 is all age 16-99. Region variables relates to region of work in column 1 and region of residence in column 2. Excluded categories: ages 16-19; Tyne \& Wear; 2004, full-time worker and white. \#under and over hours set to zero for non-workers including unpaid family workers. T-statistics in parentheses. 


\section{References}

Angrave, D. and A. Charlwood (2015), 'What is the relationship between long working hours, over-employment, underemployment and the subjective well-being of workers? Longitudinal evidence from the UK', Human Relations, 68(9), pp. 1491-1515.

Baxter, A.J., K.M. Scott, A.J. Ferrari, R.E. Norman, T. Vos and H.A. Whiteford (2014), 'Challenging the myth of an "epidemic" of common mental disorders: trends in the global prevalence of anxiety and depression between 1990 and 2010', Depression and anxiety, 31, pp.506-516.

Bell, D. N., and D.G. Blanchflower (2019), Underemployment in the US and Europe', Industrial and Labor Relations Review, forthcoming.

Bell, D.N.F. and D.G. Blanchflower (2018a), 'Underemployment and the lack of wage pressure in the UK', National Institute Economic Review, 243(1), February, pp. R53-R61.

Bell, D. N., and D.G. Blanchflower (2018b),'The lack of wage growth and the falling NAIRU', National Institute Economic Review, 244(2), August, pp. R1-R16.

Bell, D.N.F. and D.G. Blanchflower (2014), 'Labour market slack in the UK', National Institute Economic Review \#229 August, F4-F11.

Bell, D.N.F. and D.G. Blanchflower (2013), 'Underemployment in the UK revisited', National Institute Economic Review, \#224, May pp. F8-F22.

Bell, D.N.F. and D.G. Blanchflower (2011), 'Youth underemployment in the UK in the Great Recession', National Institute Economic Review, January, pp. R1-R11.

Blanchflower, D.G. and A.J. Oswald (2018), 'Is there a midlife psychological low? Two approaches (with and without controls) in six modern data sets on 1.3 million citizens?', paper to be presented at NBER conference Measurement and Tracking of Subjective Well-Being for Aging Research, July 28, 2018.

Blanchflower, D.G. and A.J. Oswald (2016), 'Antidepressants and age: a new form of evidence for U-shaped well-being through life', Journal of Economic Behavior and Organization, 127, pp. 4658 .

Blanchflower, D.G. and A.J. Oswald (2008), 'Is well-being U-shaped over the life cycle?', Social Science and Medicine, 66(8), pp. 1733-1749, April.

Dooley D. and, J. Prause (1998), 'Underemployment and alcohol misuse in the National Longitudinal Survey of Youth', Journal of Studies on Alcohol, 59, pp. 669-680.

Dooley D., J. Prause, K.A. Ham-Rowbottom (2000), ' Underemployment and depression: longitudinal relationships', Journal of Health and Social Behavior, December, 41(4), pp. 421-36. 
Friedland, D.S. and R. H. Price (2003), 'Underemployment: consequences for the health and wellbeing of workers', American Journal of Community Psychology, 32, Nos. 1/2, September, pp. 3345 .

Heyes, J. M. Tomlinson and A. Whitworth (2017), 'Underemployment and well-being in the UK before and after the Great Recession', Work, Employment and Society, 31(1), pp. 71-89.

Hong, G.H., Z. Kóczán, W. Lian, and M. Nabar (2018), 'More slack than meets the eye? Recent wage dynamics in advanced economies,' IMF Working Paper/18/50, IMF Research Department

IMF (2017), World Economic Outlook, October.

Jensen, L. and T. Slack (2003), 'Underemployment in America: measurement and evidence', American Journal of Community Psychology, 32(1/2), September, pp.21-31.

Jorm, A. F., S.B. Patten, T.S. Brugha, and R. Mojtabai, R. (2017), 'Has increased provision of treatment reduced the prevalence of common mental disorders? Review of the evidence from four countries', World Psychiatry, 16(1), pp. 90-99.

Kamerade, D. and H. Richardson (2018), 'Gender segregation, underemployment and subjective well-being in the UK labour market', Human Relations, 71 (2), pp. 285-309.

Kügler, A., U. Schönberg and R. Schreiner (2018), 'Productivity growth, wage growth and unions', paper given at ECB Forum on Central Banking Price and wage-setting in advanced economies, Sintra, Portugal, 18-20 June 2018.

Lewis, H. G. (1969), 'Employer interests in employee hours of work', Unpublished paper, University of Chicago.

New Economics Foundation (2012), 'Wellbeing uncovered: An analysis of UK data', London.

OECD (2018), Employment Outlook, 2018, Paris.

Oi, W. (1983), 'The fixed employment costs of specialized labor', In: The Measurement of Labor Cost, edited by J. Triplett, pp. 63-122. University of Chicago Press.

Prause, J., and D. Dooley (1997), 'Effect of underemployment on school-leaver's self-esteem. Journal of Adolescence, 20, pp. 243-260.

Rauch, J. (2017), The Happiness curve: Why life gets better after midlife', Thomas Dunne.

Rinne, U. and K.F. Zimmermann (2013), 'Is Germany the North Star of Labor Market Policy?', IMF Economic Review, 61, pp. 702-729

Rinne, U. and K.F. Zimmermann (2012), 'Another economic miracle? The German Labor Market and the Great Recession', IZA Journal of Labor Policy, 1:3 
Wilkins, R. (2007). 'The consequences of underemployment for the underemployed', Journal of Industrial Relations, 49, pp. 247-75.

Wooden, W. D. Warren and R. Drago (2009), 'Working time mismatch and subjective well-being, British Journal of Industrial Relations, 47:1, March, pp. 147-179.

Zapf, D., C. Dormann, and M. Frese (1996), 'Longitudinal studies in organizational stress research: A review of the literature with reference to methodological issues', Journal of Occupational Health Psychology, 1, pp. 145-169. 


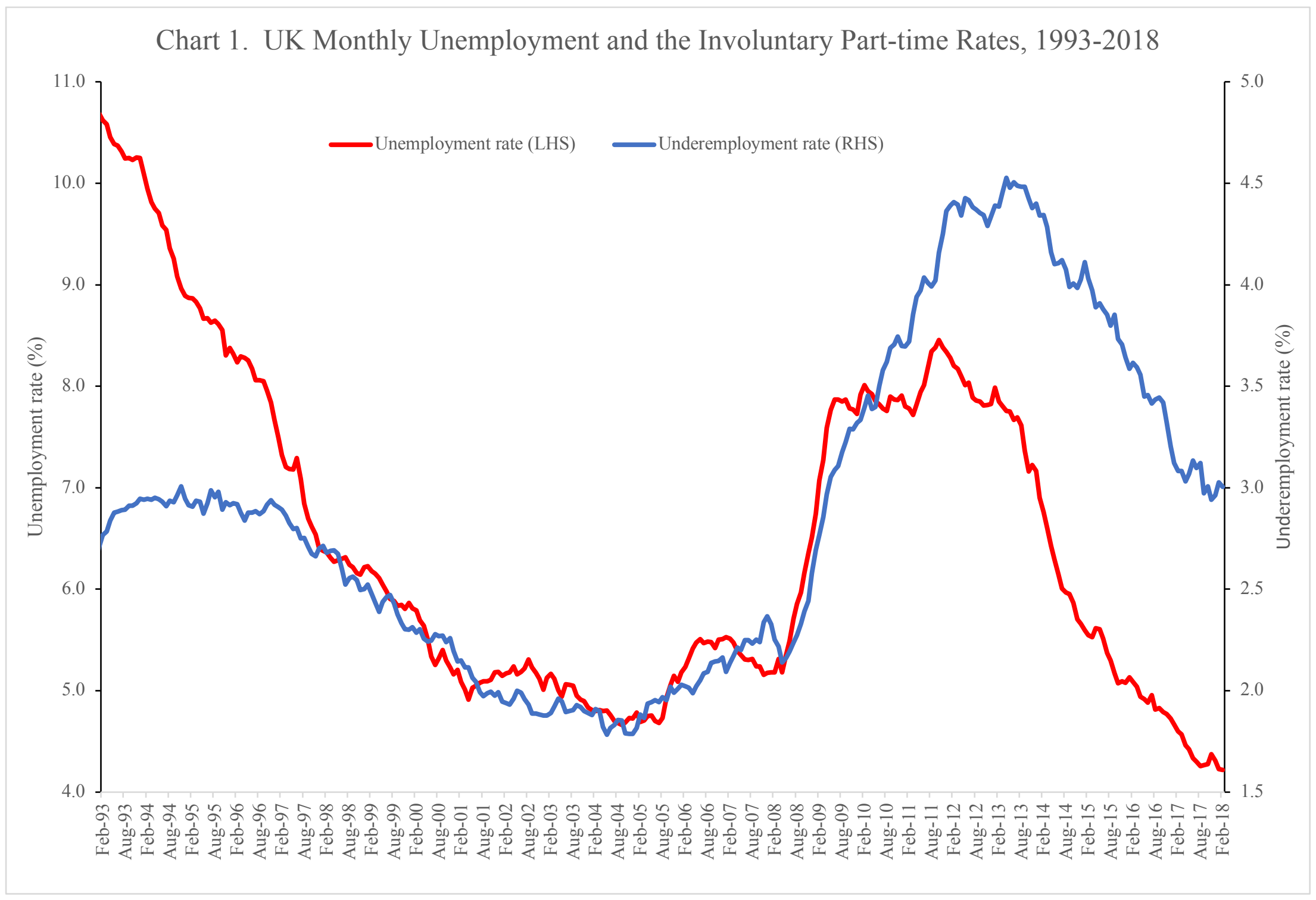


Chart 2. Aggregate More and Fewer Desired Hours

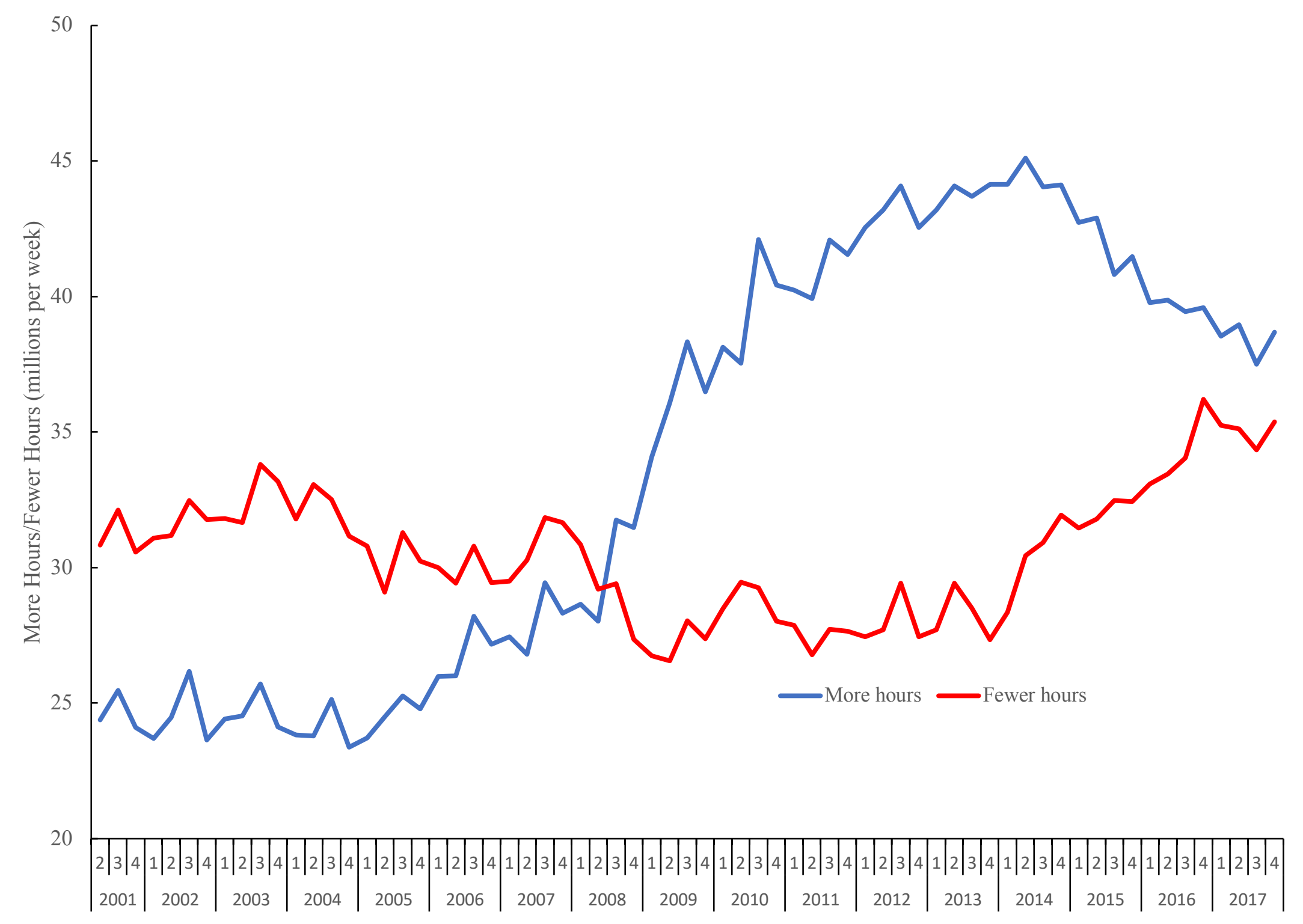




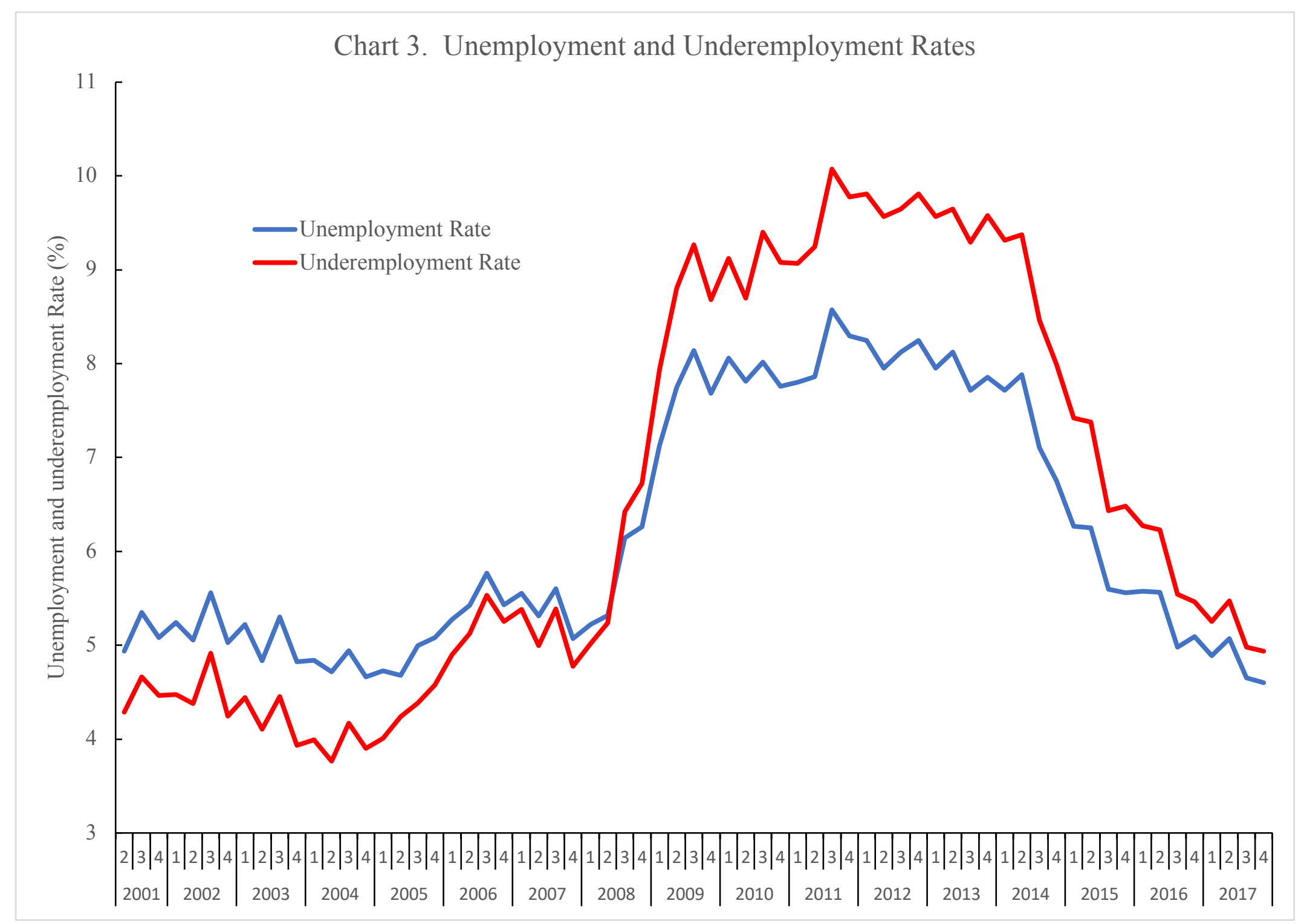




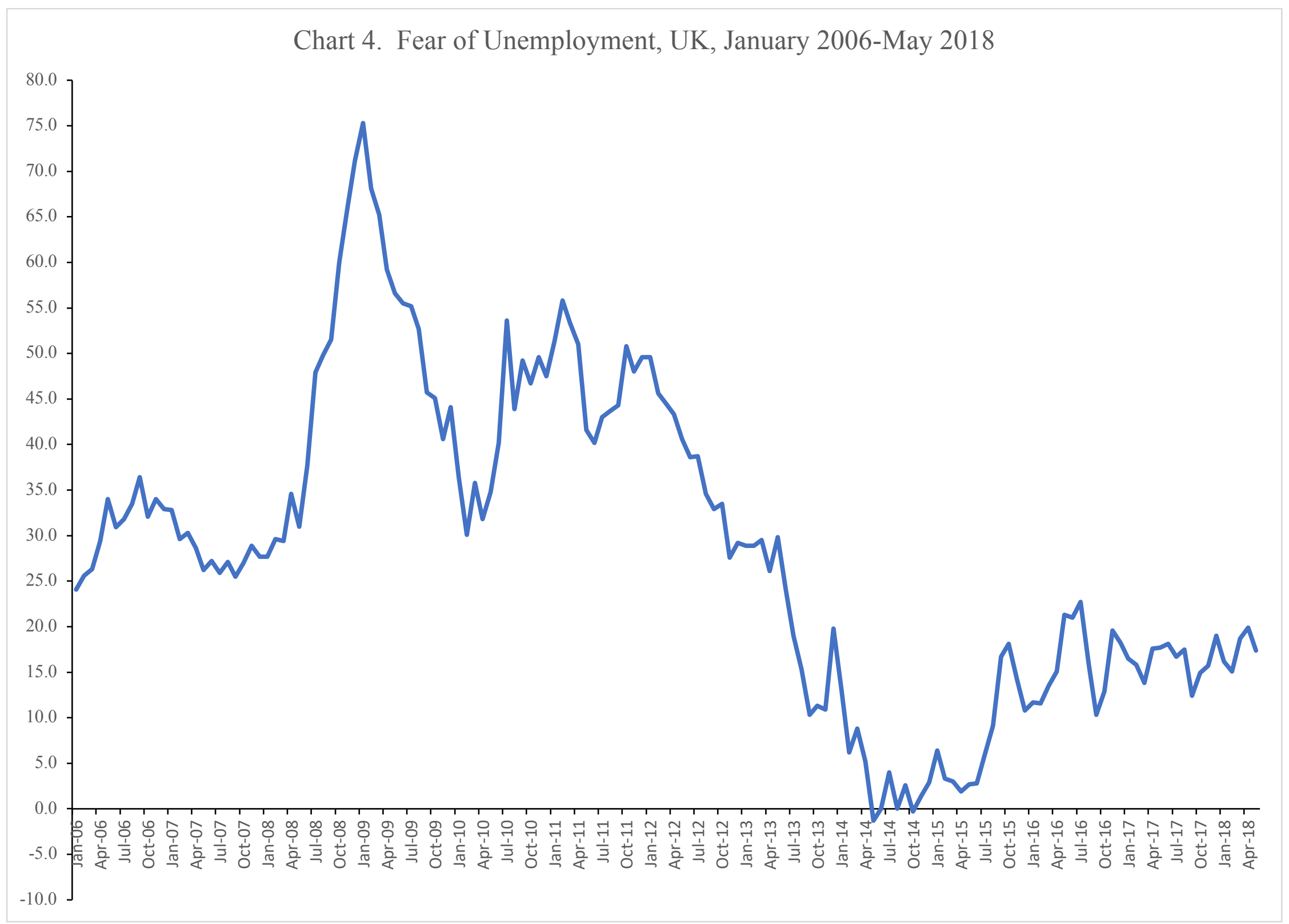




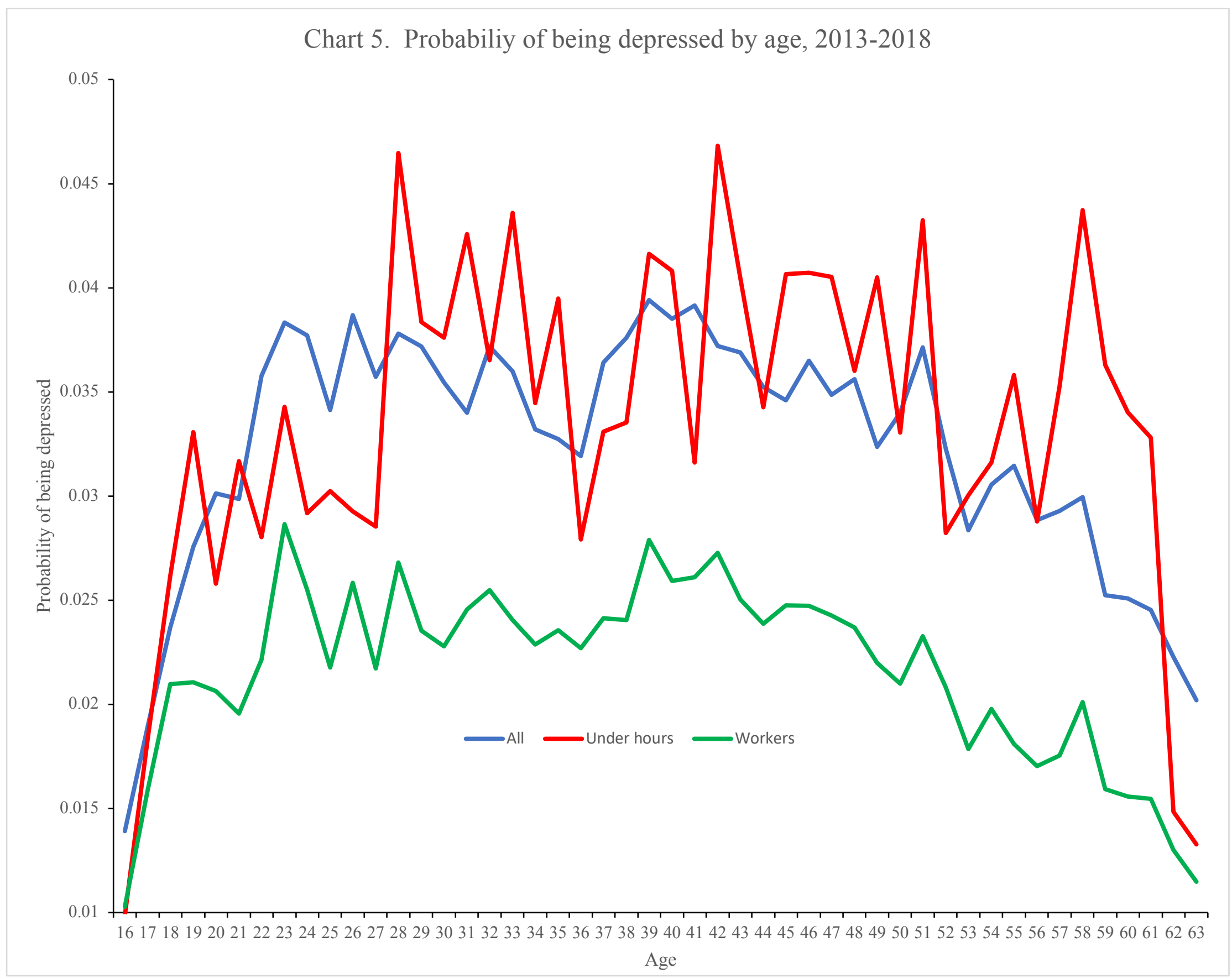


Chart 6. Probabiliy of being depressed by age for those who want fewer hours, 2013-2018

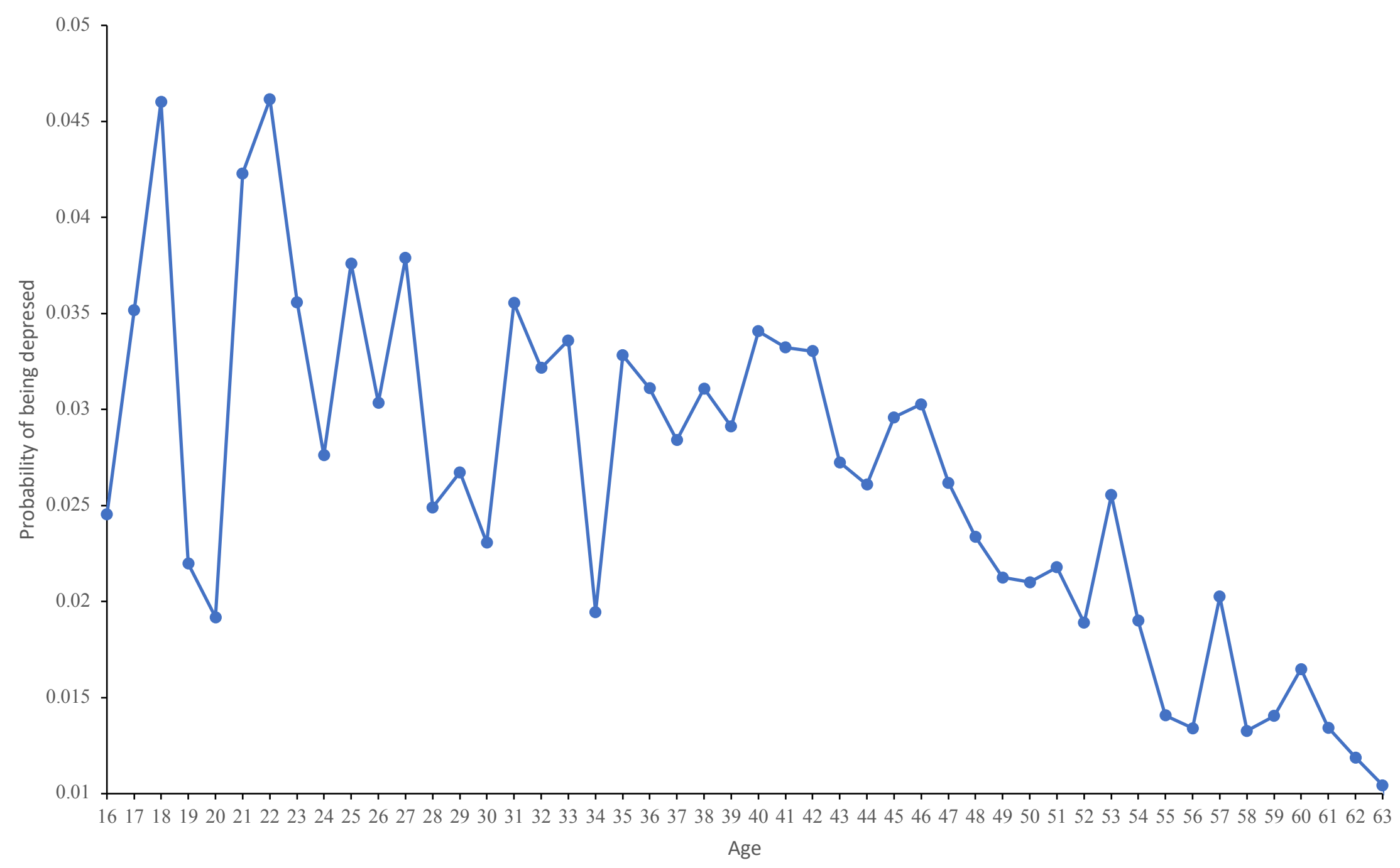


Wednesday, June 27, 2018 - 11:06:53 AM
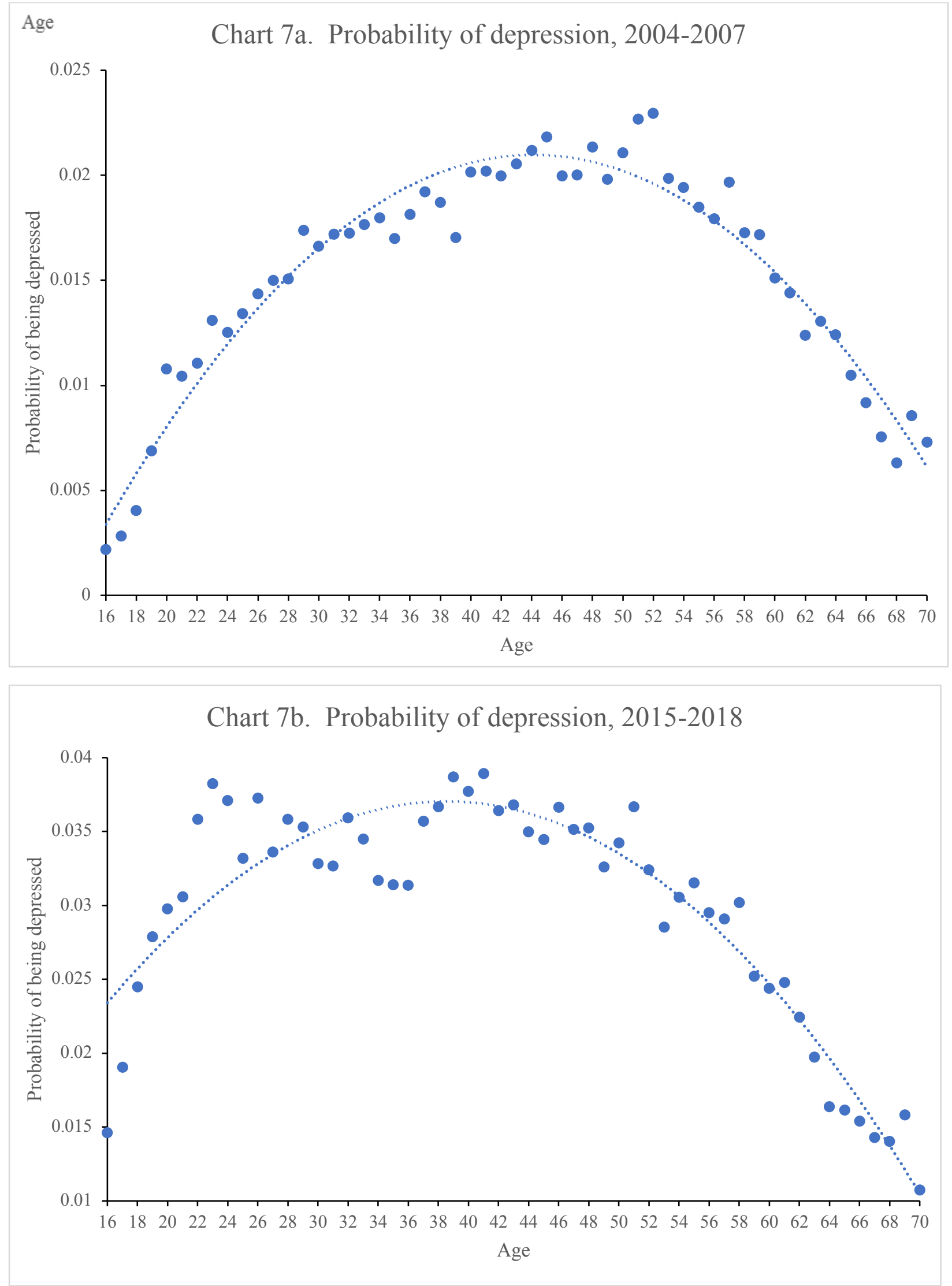